\title{
Pedogenic properties of surface deposits used as evidence for the type of landform formation of the Tadu tableland in central Taiwan
}

\author{
Heng Tsai ${ }^{\text {a,*}}{ }^{\text {, Zeng-Yei Hseu }}{ }^{\mathrm{b}}$, Shiuh-Tsuen Huang ${ }^{\mathrm{c}}$, Wen-Shu Huang ${ }^{\mathrm{a}}$, Zueng-Sang Chen ${ }^{\mathrm{d}}$ \\ a Department of Geography, National Changhua University of Education, Changhua 50007, Taiwan \\ ${ }^{\mathrm{b}}$ Department of Environmental Science and Engineering, National Pingtung University of Science and Technology, Pingtung 91201, Taiwan \\ c Department of Science Application and Dissemination, National Taichung University, Taichung 40306, Taiwan \\ d Department of Agricultural Chemistry, National Taiwan University, Taipei 10617, Taiwan
}

\section{A R T I C L E I N F O}

\section{Article history:}

Received 3 March 2009

Received in revised form 31 August 2009

Accepted 1 September 2009

Available online 11 September 2009

\section{Keywords:}

Tadu tableland

Fluvial terrace

Pedogenesis

Ultisols

Weighted profile development index (WPDI)

\begin{abstract}
A B S T R A C T
The Tadu tableland is located at the deformation front of the Western Foothills in central Taiwan. The surface of the tableland is covered by reddish soils and gravels, and is folded symmetrically with gently dipping strata running toward both wings. Previous geomorphic studies suggested a fluvial terrace landform developed on the surfaces of the tableland. However, other suggestions have been proposed in recent years. This study attempts to solve the argument by examining the pedogenesis of surface deposits.

Five soil pedons were sampled to the depths of $\mathrm{C}$ horizons in the surface deposits of the tableland. Strong migration of illuvial clay was indicated by the accumulation of significant clay coatings in the sub-surface soils. These soils were classified as Paleudult and Kandiudult of Ultisols according to Soil Taxonomy. In addition, their morphological characteristics were further quantified in terms of soil development by the horizon index and weighted profile development index (WPDI). The WPDI values of $0.64-0.73$ for the soils of the Tadu tableland agree with those of Ultisols developed on the Pakua tableland. Both qualification and quantification assessments indicate all soils of the Tadu tableland are equivalent in terms of degree of pedogenesis. As a result, all the geomorphic surfaces on the tableland probably developed at the same time, which rules out the interpretation of fluvial terraces developing on the tableland. The pedogenic evidence conditionally supports the recently proposed kinematic model for the development of the Tadu tableland.
\end{abstract}

(c) 2009 Elsevier B.V. All rights reserved.

\section{Introduction}

The Western Foothills of Taiwan are characterized by a sequential west-verging thrust-and-fold belt formed by tectonic compression from the east along the convergence boundary between the Philippine Sea plate and the Eurasian plate (Ho, 1988; Lee et al., 1996) (Fig. 1). The elongated Tadu tableland is an anticline and defines the deformation front of the Western Foothills in central Taiwan (Lee et al., 1996; Deffontaines et al., 1997). According to a field investigation and a study by Lin (1957), the tableland is covered by soil and gravel deposits with hue redder than 7.5YR on the Munsell color chart. Previous geomorphologic studies indicated fluvial terraces developed on the surfaces of the tableland, which were subsequently tilted by uplift of the anticline (Lin, 1957; Ku, 1963; Yang 1986) (Fig. 2b). However, different theories for the formation of the Tadu tableland have been proposed in recent years (CGS, 2000; Delcaillau, 2001).

Despite the great difference in height between the terrace treads on the Tadu tableland, the terrace risers are smooth with a gentle gradient between the upper and lower treads. There is no bedrock outcropping

\footnotetext{
* Corresponding author. No.1, Chinte Road, Changhua 50007, Taiwan. Tel.: +886 4 7232105 2819; fax: +886 47211186

E-mail address: geotsaih@cc.ncue.edu.tw (H. Tsai).
}

from the scarps of the terrace risers. A geologic map published by the Central Geological Survey (CGS, 1994, 2000) attributes parts of the terrace deposits to the Pleistocene conglomerates of the Tokoshan formation (Fig. 2a). Delcaillau (2001) suggested the Tadu tableland formed from the coalescence of three small and independent folds from southeast to northwest, which is supported by the landform revealed by a digital elevation model (Fig. 3). Delcaillau's theory can be easily tested using chronological data. Unfortunately, there is a lack of suitable geochronometry and an absence of datable material in the surface deposits of the tableland.

Jenny (1941) suggested most soil properties are time-dependent variables, and that soils can be used to sub-divide and correlate Quaternary successions (Morrison, 1968; Leamy et al., 1973; Mulcahy and Churchward, 1973; Birkeland, 1984). In other words, the age of the geomorphic surface is indicated by the degree of soil development. The use of the profile development index (PDI) of Harden (1982) has proven to be an easy and effective method for quantifying the field attributes of soils to rank soil development (Bockheim et al., 1992; Alonso et al., 1994). Tsai et al. (2007a,b) used the weighted profile development index (WPDI) to correlate river terraces in central Taiwan to gauge deformation due to regional tectonics. The identification of geomorphic surfaces on the Tadu tableland will provide important information for understanding the landform 

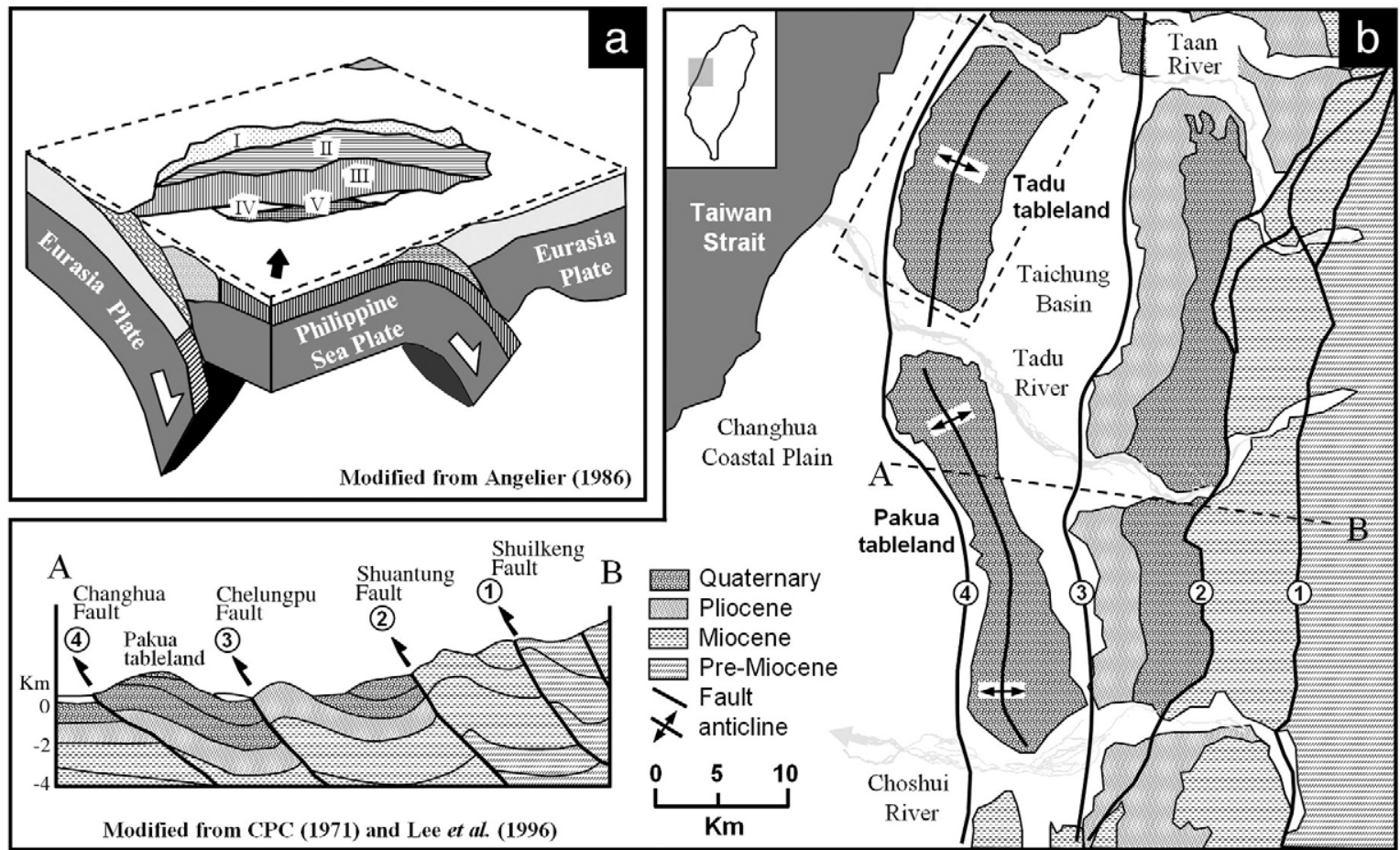

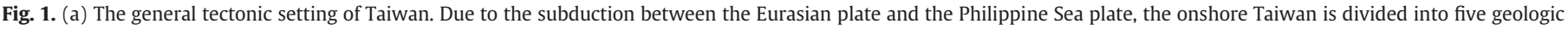

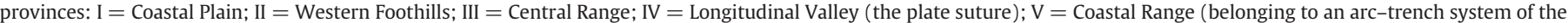

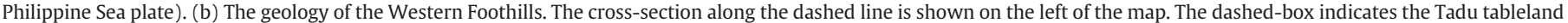
which is further detailed in Figs. 2 and 3.

formation and its link to tectonic processes that have occurred in the area. In this study, the surface deposits of the Tadu tableland are examined and quantified by their morphologic properties on the basis of the scheme of Harden (1982). The goals of this study are to (i) evaluate the degree of pedogenic development of the surface deposits on the Tadu tableland, (ii) identify the geomorphic surfaces and achieve regional correlation based on soil pedogenesis, and (iii) provide evidence for the testing of the above theorem for landform formation on the Tadu tableland.

\section{Geology and landform}

Taiwan is an island located at the convergent boundary where the Philippine Sea plate subducts beneath the Eurasian plate (Tsai, 1986;

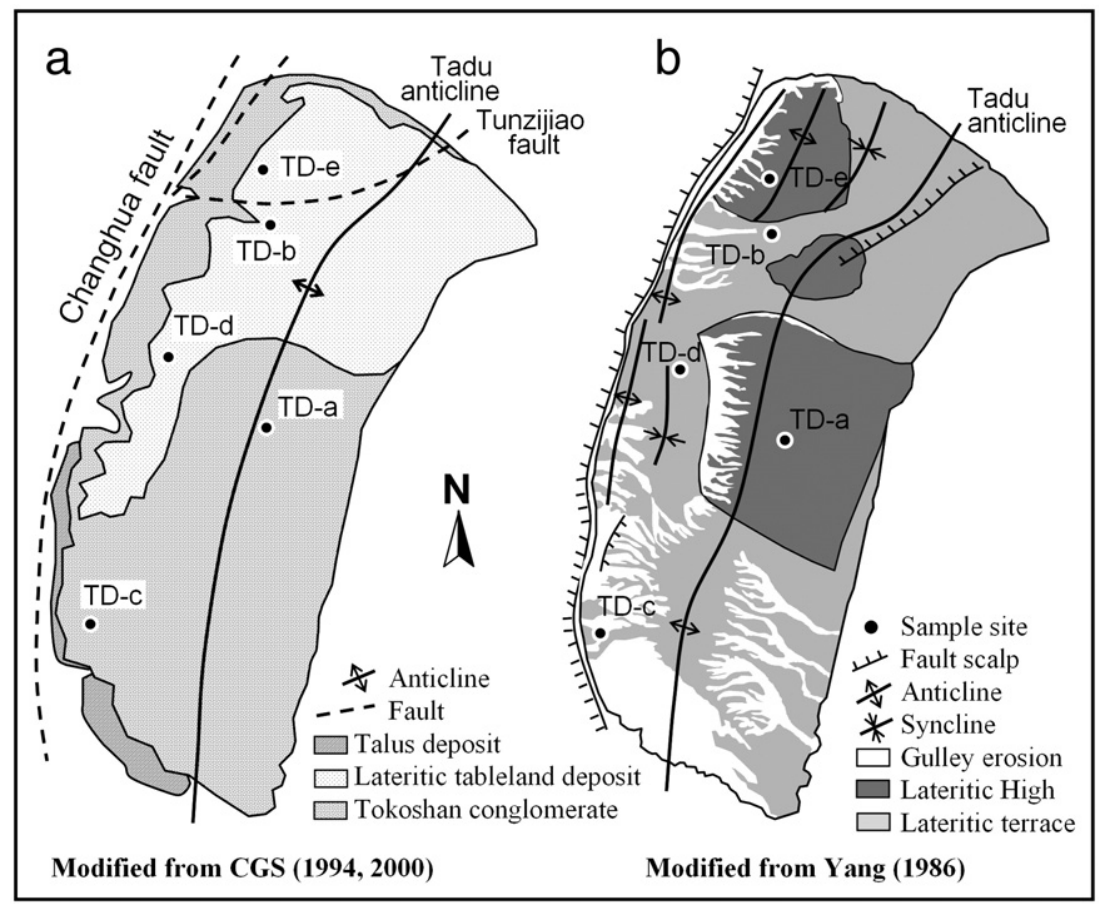

Fig. 2. (a) The geologic map of the Tadu tableland; (b) the geomorphic interpretation of terrace landform for the surfaces of the Tadu tableland. 


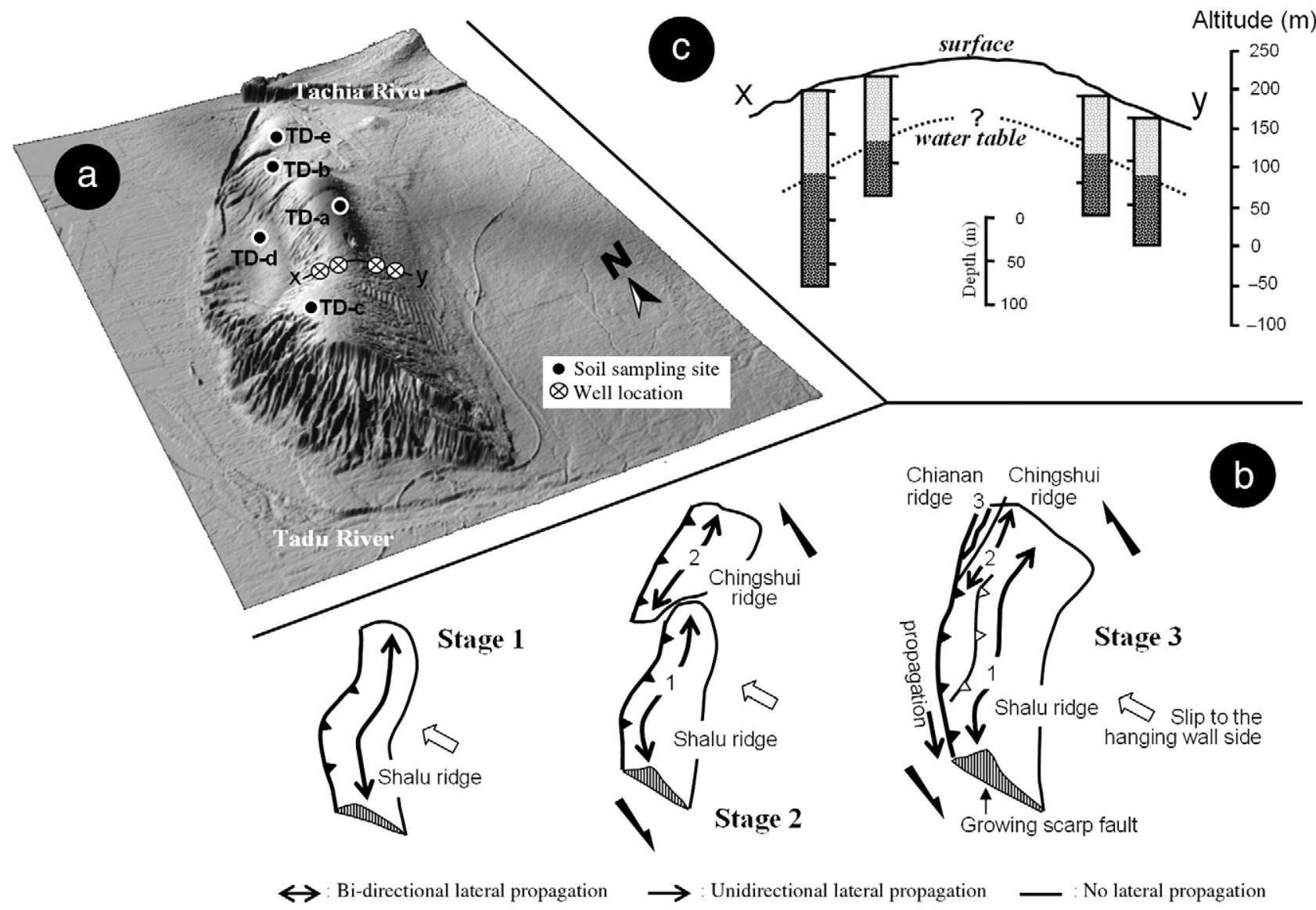

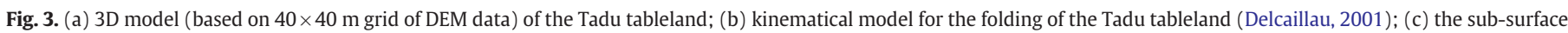
water table indicated by the wells (unpublished data; courtesy of Taiwan Sugar Corporation).

Angelier, 1986) (Fig. 1). The active tectonics results in a mountainous landscape with a complex geologic framework below the surface (Lin, 1957; Ho, 1988). The 10-20 km-wide Western Foothills are composed of a thin-skinned fold and thrust belt that flanks the Central Ranges along much of its length. They were developed by the sequential thrusting of a series of sub-parallel reverse faults formed by westward tectonic compression since the Plio-Pleistocene (Lee et al., 1996) (Fig. 1). The elongated Tadu tableland is a hanging-wall anticline caused by frontal thrusting of the Changhua fault, and it exhibits an up-warp landform across a hinge with smooth surfaces (Figs. 1, 3a). In contrast to the asymmetric anticline of the Pakua tableland, which is separated by the Choshui River, the Tadu tableland is symmetrically folded with gently dipping strata running toward both wings (Lin, 1957) (Fig. 3). The discharge from the Choshui River (the longest river in Taiwan) is dark and has a high sediment load eroded from slate, phyllite, and quartzite of the Tertiary metamorphic terrain (Lin, 1957; Ho, 1988). Mean annual suspended sediment flux from the Choshui river reaches $54 \mathrm{Mt} / \mathrm{year}$ (Dadson et al., 2003). There is a seismic fault, the Tunzijiao fault, across the northwestern corner of the tableland, the surface ruptures of which have been associated with a 1935 earthquake (local magnitude of 7.1 on the Richter scale). This fault extends $14 \mathrm{~km}$ and produced a right-lateral displacement of less than $2 \mathrm{~m}$ during the earthquake. Delcaillau (2001) suggested the Tadu tableland formed from the southeast to northwest coalescence of three small and independent folds.

The surface of the Tadu tableland is covered by reddish soils (redder than 7.5YR on the Munsell color chart) and rounded gravels, which are well preserved owing to mild gully erosion. A soil layer measuring 2-4 $\mathrm{m}$ in thickness extends above the gravel bed throughout the tableland. According to previous geomorphologic studies, these fluvial deposits were conjointly deposited by the Tachia and Tadu Rivers, leaving river terraces on the tableland surface (Lin, 1957; Ku, 1963; Yang, 1986). Both rivers carry similar sediments eroded mainly from the same geologic terrains with identical rock types (Lin, 1957; Ho, 1988). The red soils were developed from the layer of sands and suspended sediments deposited above the gravels. The uplifting and folding of the tableland are responsible for the subsequent river incisions. All surface deposits have long been known as "lateritic tableland deposits" to local geologists. However, a recently published geologic map identifies two geologic units for the surface deposits: lateritic tableland deposits in the north and the weathering phase of the Tokoshan conglomerate in the middle and south of the tableland (CGS, 1994, 2000) (Fig. 2a). The Pleistocene Tokoshan formation comprises two different lithological units: upper conglomeratic deposits with thin sand layers and lower sandstones with intercalated conglomerate. The lateritic tableland deposits consist of reddish soils and gravels, the strata of which lie above the Tokoshan formation in a sequence with angular unconformity. However, it is difficult to distinguish between the gravel beds of the Tokoshan conglomerate and those of the lateritic tableland deposits. The boundary of the unconformity is ambiguous and hard to identify in the field.

Yang (1986) identified two levels of river terracing on the surface of the Tadu tableland as LH and LT1 following the correlation scheme established by Lin (1957) and Tomida (1972). LH denotes the "Lateritic Highland" representing the peneplain of the previous cycle of erosion. Lee et al. (1999) suggested a maximum age of more than $900 \mathrm{ka}$ for the LH in northern Taiwan. Tsai et al. (2006, 2008) gave a younger age about $400 \mathrm{ka}$ for the LH on the Pakua tableland in central Taiwan. LT denotes the "Lateritic Terrace" associated with fluvial process which develops LT1, LT2, LT3..., in order of decreasing altitude, by successive river incisions from the LH 
surface. Limited radiocarbon $\left({ }^{14} \mathrm{C}\right)$ dating suggests the LT surfaces formed prior to $30 \mathrm{ka}$ BP (Liew, 1988; Chen and Liu, 1991; Ota et al., 2002). Both LH and LT are characterized by the reddish surface deposits and the altitude of $>100 \mathrm{~m}$ above the present river channel (Lin, 1957). As a result, the identification of LH and LT surfaces is practically easy and is widely used in regional correlation for geomorphic surfaces without absolute dating (Yang, 1986). Hsieh (2007) challenged the existence and validity of the LH surfaces. Many of the LH surfaces were fluvial aggradated, which has nothing to do with the stage of denudation along the cycle of erosion by William Morris Davis. Moreover, the active and complex regional tectonics and the discrepancy on the age presented in recent years encourage further adjustment or modification on previous terrace correlation (Tsai and Sung, 2003; Hsieh, 2007).

\section{Material and methods}

\subsection{Soil sampling}

Five soil pedons were sampled to the depths of $\mathrm{C}$ horizons where terrace surfaces had been identified in previous geomorphologic studies (Table 1, Figs. 2b, 3a). The sampling sites on the planar surface were carefully chosen such that there was no gully erosion, except for the sampling site for pedon TD-a, which was near a canal for draining water overflow. Each pedon is considered to be representative of its terrace because of the homogeneity of soil characteristics indicated by the generally uniform color and thickness of soils in each terrace and the uniform climatic conditions in the area. The field characteristics of the soils were described following the guidelines in the Soil Survey Manual (Soil Survey Staff, 1993). Kubiena boxes were prepared to collect undisturbed soil blocks from selected horizons in the field for further examination at a microscopic level. After air drying, vertically oriented thin sections with a thickness of $30 \mu \mathrm{m}$ were prepared by Spectrum Petrographics Inc. (Washington, USA) and then examined under a polarizing microscope and described according to the terminology of Bullock et al. (1985).

\subsection{Soil morphology quantification}

The field morphology of the soils was quantified following Harden (1982) and Harden and Taylor (1983) with minor modification. The PDIs of the pedons were calculated on the basis of six properties: (i) rubification (moist and dry soil color hue and chroma in the Munsell color chart), (ii) total texture (texture class plus degree of

Table 1

General information of the terraces and the soils of Tadu tableland.

\begin{tabular}{|c|c|c|c|c|c|c|}
\hline \multirow[t]{2}{*}{ Pedon } & \multirow{2}{*}{$\begin{array}{l}\text { Altitude } \\
(\mathrm{m})\end{array}$} & \multirow{2}{*}{$\begin{array}{l}\text { Depth }^{\mathrm{a}} \\
(\mathrm{cm})\end{array}$} & \multirow[t]{2}{*}{ WPDI } & \multirow[t]{2}{*}{ Taxonomy $^{\mathrm{b}}$} & \multicolumn{2}{|l|}{ Correlation } \\
\hline & & & & & Geomorphic $^{c}$ & Pedogenic $^{\mathrm{d}}$ \\
\hline \multicolumn{7}{|c|}{ Tadu tableland } \\
\hline TD-a & 313 & 260 & 0.66 & Typic Kandiudult & LH & II \\
\hline TD-b & 187 & 300 & 0.68 & Typic Paleudult & LT1 & II \\
\hline TD-c & 270 & 500 & 0.64 & Typic Kandiudult & LT1 & II \\
\hline TD-d & 57 & 400 & 0.67 & Typic Paleudult & LT1 & II \\
\hline TD-e & 219 & 200 & 0.73 & Typic Paleudult & $\mathrm{LH}$ & II \\
\hline \multicolumn{7}{|c|}{ Pakua tableland ${ }^{\mathrm{d}}$} \\
\hline PK-1 & 443 & 330 & 0.73 & Typic Hapludox & $\mathrm{LH}$ & I \\
\hline PK-2 & 431 & $>180$ & 0.68 & Typic Paleudult & LT1 & II \\
\hline PK-3 & 410 & 160 & 0.64 & Typic Paleudult & LT2 & III \\
\hline PK-4 & 386 & 100 & 0.58 & Typic Hapludult & LT3 & IV \\
\hline PK-5 & 330 & 140 & 0.53 & Typic Paleudult & LT4 & $\mathrm{V}$ \\
\hline PK-6 & 320 & 114 & 0.43 & Typic Dystrudept & LT5 & VI \\
\hline
\end{tabular}

a Solum thickness above $\mathrm{C}$ horizon.

b Based on Soil Taxonomy by Soil Survey Staff (1993).

c From Yang (1986).

${ }^{d}$ From Tsai et al. (2007a). stickiness and plasticity for a wet soil consistency), (iii) structure (type and degree of development of the soil structure), (iv) moisture consistency (class), (v) dryness consistency (class), and (vi) clay coating (abundance, thickness, and location). The $\mathrm{pH}$ and color value (lightness) of soil used in the original method of Harden (1982) were not included in our calculation. The $\mathrm{pH}$ was omitted because of its susceptibility to disturbance by human activities such as plowing and fertilization in the study area. The color value of the soils has been considered an important soil property mainly in the early stages of pedogenesis because organic matter content seems to increase relatively rapidly and reach a steady state faster than any other soil property (Birkeland, 1999). The organic matter in soils becomes very low after long-term development, leading to an insignificant variation in the color value. As a result, the color value is ignored in the calculation.

The horizon index (HI) and PDI were calculated by comparing the soil properties of a horizon with those of the assumed parent material. In this study, the sediments of the present active floodplains were used to represent fresh and unoxidized parent material of the soils. Although there is the possibility that the parent material includes alluviums of the Tachia and/or Tadu Rivers in various proportions, the properties taken into account for the calculation of the indices do not change. The PDI values were divided by the depth of the described soil profile to produce weighted mean PDI (WPDI) normalized values ranging between 0 (no development) and 1 (maximum development) (Birkeland, 1999).

\subsection{Physical and chemical analysis}

Soil samples were collected from each horizon for physical and chemical analyses. Bulk density was determined using the core method (Blake and Hartge, 1986). The particle size distribution was determined using the pipette method (Gee and Bauder, 1986). The $\mathrm{pH}$ of air-dried samples (soil particle size less than $2 \mathrm{~mm}$ ) was determined for a mixture of soil/deionized water (1:1) using a glass electrode (McLean, 1982). Organic carbon content was measured using the Walkley-Black wet oxidation method (Nelson and Sommers, 1982). Cation exchange capacity (CEC) and exchangeable base content were measured using the ammonium acetate method $(\mathrm{pH}$ 7.0) (Rhoades, 1982). Free $\mathrm{Fe}\left(\mathrm{Fe}_{\mathrm{d}}\right)$ was extracted using the dithionite-citrate-bicarbonate method (Mehra and Jackson, 1960). Amorphous $\mathrm{Fe}\left(\mathrm{Fe}_{\mathrm{o}}\right)$ was extracted using $0.2 \mathrm{M}$ ammonium oxalate (pH 3.0) (McKeague and Day, 1966). All metal contents were determined by atomic absorption spectrometry (Z-8100, Hitachi, Tokyo, Japan).

\section{Results}

\subsection{Soil morphology and laboratory analysis}

The soil pedons sampled from the Tadu tableland are about 2 to $5 \mathrm{~m}$ in thickness from the surface to the depth of the $\mathrm{C}$ horizon. The soil morphology is similar among pedons. For instance, argillic horizons (Bt) in all pedons are strongly characterized by a reddish hue ranging from 2.5YR to $10 \mathrm{R}$ with high value and chroma (Table 2 ). Fine texture with high clay content of sub-surface horizons results in a very sticky and plastic consistency, and coarse and strong angular blocky structures (Fig. 4). Strong granular structures are easily found in the A horizons of pedons TD- $d$ and TD-e. Clay coatings are commonly observed in the Bt horizons. Except for pedon TD-e, each soil pedon has a bisequal profile that includes a cambic upper sequum (A-Bw) overlying a sequence of $2 \mathrm{Bt}-2 \mathrm{C}$ horizons.

The identification of clay illuviation is further supported by the diverse microtextures of clay accumulation. There are thick crescent coatings with strong birefringency filling the chambers of the soil matrix in Bt horizons (Fig. 5a). Illuvial clays capping the coarse 
Table 2

Field morphological characteristics of the soils.

\begin{tabular}{|c|c|c|c|c|c|c|c|c|c|c|}
\hline \multirow[t]{2}{*}{ Pedon } & \multirow[t]{2}{*}{ Horizon } & \multirow{2}{*}{$\begin{array}{l}\text { Depth } \\
(\mathrm{cm})\end{array}$} & \multicolumn{2}{|c|}{ Munsell color } & \multirow[t]{2}{*}{ Texture $^{a}$} & \multirow[t]{2}{*}{ Structure $^{\mathrm{b}}$} & \multicolumn{3}{|c|}{ Consistence $^{\mathrm{C}}$} & \multirow[t]{2}{*}{ Clay coatings ${ }^{\mathrm{d}}$} \\
\hline & & & Moist & Dry & & & Dry & Moist & Wet & \\
\hline \multirow[t]{12}{*}{$T D-a$} & BA & $0-20$ & 5YR 5/8 & 5YR 6/8 & $\mathrm{CL}$ & 2f\&mabk & $\mathrm{h}$ & fir & ss,ps & $-^{\mathrm{e}}$ \\
\hline & Bw1 & $20-50$ & 5YR 4/6 & 5YR 6/8 & $\mathrm{CL}$ & 2f\&mabk & $\mathrm{h}$ & fir & ss,ps & - \\
\hline & Bw2 & $50-70$ & 5YR 4/6 & 5YR 6/8 & $\mathrm{CL}$ & $2 \mathrm{f} \& \mathrm{mabk}$ & $\mathrm{h}$ & fir & $\mathrm{s}, \mathrm{p}$ & - \\
\hline & Bw3 & $70-90$ & $2.5 Y R \quad 4 / 6$ & 5YR 6/8 & $\mathrm{CL}$ & $2 \mathrm{mabk} \& \mathrm{sbk}$ & $\mathrm{h}$ & fir & $\mathrm{s}, \mathrm{p}$ & - \\
\hline & 2Bt1 & $90-110$ & $2.5 Y R \quad 4 / 8$ & 2.5 YR $6 / 8$ & $\mathrm{CL}$ & $3 \mathrm{~m} \& \mathrm{cabk}$ & vh & vfir & $\mathrm{vs,vp}$ & $1 \mathrm{fpf}$ \\
\hline & 2Bt2 & 110-135 & $2.5 Y R \quad 3 / 6$ & 2.5 YR 5/6 & $\mathrm{C}$ & $3 c \& v c a b k$ & vh & vfir & vs,vp & 3dpf \\
\hline & $2 \mathrm{Bt} 3$ & 135-155 & $2.5 Y R \quad 4 / 6$ & 2.5 YR $5 / 8$ & C & 3mc\&vcabk & vh & vfir & vs,vp & 3dpf \\
\hline & $2 \mathrm{Bt} 4$ & $155-175$ & $2.5 Y R \quad 3 / 6$ & 2.5 YR $5 / 8$ & C & $3 c \& v c a b k$ & vh & vfir & vs,vp & 3dpf \\
\hline & $2 \mathrm{Bt} 5$ & $175-200$ & $2.5 Y R \quad 4 / 6$ & 2.5 YR $5 / 8$ & $\mathrm{C}$ & $3 \mathrm{~m} \& \mathrm{cabk}$ & vh & vfir & $\mathrm{vs,vp}$ & $2 \mathrm{dpf}$ \\
\hline & $2 \mathrm{Bt} 6$ & $200-230$ & $2.5 Y R \quad 4 / 8$ & 2.5 YR $5 / 8$ & $\mathrm{C}$ & $3 \mathrm{~m} \& \mathrm{cabk}$ & vh & vfir & vs,vp & $2 \mathrm{dpf}$ \\
\hline & $2 \mathrm{BC}$ & $230-260$ & 10R $4 / 8$ & 10R $5 / 8$ & C & $2 \mathrm{~m} \& \mathrm{cabk}$ & $\mathrm{h}$ & vfir & $\mathrm{s}, \mathrm{p}$ & - \\
\hline & $2 \mathrm{C}$ & $>260$ & $10 \mathrm{R} 4 / 8$ & 10R 5/8 & $\mathrm{CL}$ & $2 \mathrm{~m} \& \mathrm{cabk}$ & $\mathrm{h}$ & vfir & $\mathrm{s}, \mathrm{p}$ & \\
\hline \multirow[t]{13}{*}{$T D-b$} & $\mathrm{BA}$ & $0-20$ & 5YR 5/6 & 5YR 6/6 & $\mathrm{CL}$ & 2f\&mabk & $\mathrm{h}$ & fir & ss,ps & - \\
\hline & Bw1 & $20-35$ & 5YR 5/6 & 5YR 6/6 & $\mathrm{L}$ & $3 f \& m a b k$ & $\mathrm{~h}$ & fir & ss,ps & - \\
\hline & Bw2 & $35-60$ & 5YR 4/6 & 5YR 6/8 & $\mathrm{L}$ & $3 f \&$ mabk & vh & vfir & $\mathrm{s}, \mathrm{p}$ & - \\
\hline & $2 \mathrm{Bt} 1$ & $60-85$ & 5YR 5/8 & 5YR 6/8 & $\mathrm{CL}$ & 3fm\&cabk & vh & fir & $\mathrm{s}, \mathrm{p}$ & v1fpo \\
\hline & 2Bt2 & $85-110$ & $2.5 Y R \quad 4 / 8$ & 2.5 YR $5 / 8$ & $\mathrm{CL}$ & 3f\&mabk & vh & vfir & vs,vp & $1 \mathrm{fpf}$ \\
\hline & $2 \mathrm{Bt} 3$ & $110-130$ & $2.5 Y R \quad 4 / 8$ & 2.5 YR $5 / 8$ & $\mathrm{CL}$ & $3 f \& m a b k$ & vh & vfir & vs,vp & $1 \mathrm{fpf}$ \\
\hline & $2 \mathrm{Bt} 4$ & $130-155$ & $2.5 Y R$ 4/8 & 2.5YR 5/8 & $\mathrm{CL}$ & $3 \mathrm{fm} \& \mathrm{cabk}$ & vh & vfir & vs,vp & $2 \mathrm{fpf}$ \\
\hline & $2 \mathrm{Bt} 5$ & $155-180$ & $2.5 Y R \quad 4 / 6$ & 2.5 YR 5/8 & $\mathrm{C}$ & $3 \mathrm{~m} \& \mathrm{cabk}$ & vh & vfir & vs,vp & $3 \mathrm{fpf}$ \\
\hline & $2 \mathrm{Bt} 6$ & $180-210$ & $10 \mathrm{R} 4 / 6$ & 10R $5 / 8$ & C & $3 \mathrm{~m} \& \mathrm{cabk}$ & eh & vfir & vs,vp & $3 \mathrm{dpf}$ \\
\hline & $2 \mathrm{Bt} 7$ & $210-240$ & $10 \mathrm{R} 4 / 8$ & 10R 5/8 & C & $3 \mathrm{~m} \& \mathrm{cvcabk}$ & vh & vfir & vs,vp & $3 \mathrm{dpf}, 1 \mathrm{fpo}$ \\
\hline & $2 \mathrm{BC} 1$ & $240-270$ & $10 \mathrm{R} 4 / 8$ & 10R 5/8 & $\mathrm{CL}$ & $3 \mathrm{mabk}$ & vh & fir & $\mathrm{s}, \mathrm{vp}$ & - \\
\hline & $2 \mathrm{BC} 2$ & $270-300$ & $10 \mathrm{R} 4 / 8$ & 10R 5/8 & $\mathrm{CL}$ & 3 mabk & vh & fir & $\mathrm{s}, \mathrm{p}$ & - \\
\hline & $2 \mathrm{C}$ & $>300$ & $10 \mathrm{R} 4 / 8$ & 10R 5/8 & $\mathrm{CL}$ & 2f\&mabk & $\mathrm{h}$ & fir & ss,ps & - \\
\hline$T D-c$ & BA & $0-20$ & 5YR 5/8 & 5YR 6/8 & $\mathrm{CL}$ & $2 \mathrm{msbk} \& \mathrm{cabk}$ & $\mathrm{h}$ & fir & ss,ps & \\
\hline & Bw1 & $20-45$ & 5YR 5/8 & 5YR 6/8 & $\mathrm{CL}$ & 2f\&mabk & $\mathrm{h}$ & fir & ss,ps & - \\
\hline & Bw2 & $45-70$ & 5YR 5/8 & 5YR 6/8 & $\mathrm{L}$ & $2 \mathrm{fm} \& \mathrm{cabk}$ & vh & vfir & ss,ps & - \\
\hline & Bw3 & $70-90$ & 5YR 6/8 & 5YR 7/8 & $\mathrm{CL}$ & $3 \mathrm{~m} \& \mathrm{cabk}$ & vh & vfir & $\mathrm{vs,vp}$ & - \\
\hline & Bw4 & $90-115$ & 5YR 5/8 & 5YR 6/8 & $\mathrm{CL}$ & $2 \mathrm{f} \& \mathrm{mabk}$ & vh & fir & $\mathrm{vs,vp}$ & - \\
\hline & $2 \mathrm{Bt} 1$ & $115-140$ & 5YR 4/6 & 5YR 5/6 & $\mathrm{CL}$ & $3 c \& v c a b k$ & vh & vfir & $\mathrm{s}, \mathrm{p}$ & v1fpf \\
\hline & $2 \mathrm{Bt} 2$ & $140-165$ & 5YR 4/6 & 5YR 5/6 & $\mathrm{CL}$ & $3 \mathrm{~m} \& \mathrm{cabk}$ & vh & vfir & $\mathrm{s}, \mathrm{p}$ & $1 \mathrm{fpf}$ \\
\hline & $2 \mathrm{Bt} 3$ & $165-190$ & $2.5 Y R \quad 4 / 6$ & $2.5 Y R$ 5/6 & $\mathrm{C}$ & $3 \mathrm{mc} \& \mathrm{vcabk}$ & vh & vfir & $\mathrm{vs,vp}$ & $2 \mathrm{dpf}$ \\
\hline & $2 \mathrm{Bt} 4$ & $190-210$ & 5YR 3/6 & 2.5 YR 5/6 & C & 3mc\&vcabk & vh & vfir & $\mathrm{vs,vp}$ & $2 \mathrm{dpf}$ \\
\hline & $2 \mathrm{Bt} 5$ & $210-235$ & $2.5 Y R \quad 3 / 6$ & 2.5 YR $5 / 6$ & C & $3 \mathrm{~m} \& \mathrm{cabk}$ & vh & vfir & $\mathrm{vs,vp}$ & 3dpf \\
\hline & 2Bt6 & $235-260$ & $2.5 Y R \quad 4 / 8$ & 2.5 YR $5 / 8$ & $\mathrm{C}$ & $3 \mathrm{mc} \& \mathrm{vcabk}$ & vh & vfir & $\mathrm{s}, \mathrm{p}$ & $2 \mathrm{fpf}$ \\
\hline & 2Bw1 & $260-290$ & $2.5 Y R \quad 4 / 8$ & 2.5 YR $5 / 8$ & C & $3 \mathrm{~m} \& \mathrm{cabk}$ & vh & fir & $\mathrm{s}, \mathrm{p}$ & - \\
\hline & 2Bw2 & $290-320$ & $2.5 Y R \quad 3 / 6$ & 2.5 YR $5 / 8$ & C & $3 \mathrm{~m} \& \mathrm{cabk}$ & vh & fir & $\mathrm{s}, \mathrm{p}$ & - \\
\hline & 2Bw3 & $320-350$ & $2.5 Y R \quad 3 / 6$ & 2.5 YR $5 / 8$ & $\mathrm{C}$ & $3 \mathrm{~m} \& \mathrm{cabk}$ & vh & fir & $\mathrm{s}, \mathrm{p}$ & - \\
\hline & $2 \mathrm{BC} 1$ & $350-380$ & $2.5 Y R \quad 4 / 6$ & 2.5 YR $5 / 8$ & $\mathrm{C}$ & $3 \mathrm{fm} \& \mathrm{cabk}$ & $\mathrm{h}$ & fir & $\mathrm{s}, \mathrm{p}$ & - \\
\hline & $2 \mathrm{BC} 2$ & $380-410$ & $10 \mathrm{R} 4 / 6$ & 10R $5 / 8$ & C & $3 \mathrm{~m} \& \mathrm{cabk}$ & vh & fir & $\mathrm{vs}, \mathrm{vp}$ & - \\
\hline & $2 \mathrm{BC} 3$ & $410-440$ & $10 \mathrm{R} 4 / 6$ & 10R 5/8 & $\mathrm{CL}$ & $2 \mathrm{~m} \& \mathrm{cabk}$ & vh & fir & vs,vp & - \\
\hline & $2 \mathrm{BC} 4$ & $440-470$ & $10 \mathrm{R} 4 / 6$ & 10R 5/8 & $\mathrm{CL}$ & $3 \mathrm{~m} \& \mathrm{cabk}$ & vh & fir & vs,vp & - \\
\hline & $2 \mathrm{BC} 5$ & $470-500$ & $10 \mathrm{R} 4 / 8$ & 10R 5/8 & $\mathrm{CL}$ & 2f\&mabk & $\mathrm{h}$ & fir & $\mathrm{s}, \mathrm{p}$ & - \\
\hline & $2 C$ & $>500$ & $10 \mathrm{R} 4 / 6$ & 10R 6/8 & $\mathrm{CL}$ & 2f\&mabk & $\mathrm{h}$ & fir & ss,ps & \\
\hline$T D-d$ & BA & $0-20$ & 7.5YR 4/6 & 7.5YR 5/4 & SL & $3, \mathrm{fm}, \mathrm{gr}$ & $\mathrm{h}$ & fir & so,po & - \\
\hline & Bw & $20-50$ & $7.5 Y R \quad 4 / 6$ & 7.5YR 6/6 & SL & $3, \mathrm{fm}, \mathrm{abk}$ & vh & fir & ss,po & - \\
\hline & 2Bt1 & $50-90$ & 5YR 4/6 & 5YR 5/8 & $\mathrm{CL}$ & $3, \mathrm{~m}, \mathrm{abk}$ & eh & fir & $\mathrm{s}, \mathrm{p}$ & $1 \mathrm{fpo}$ \\
\hline & 2Bt2 & $90-140$ & $2.5 Y R \quad 4 / 6$ & 2.5 YR $5 / 8$ & $\mathrm{CL}$ & 3, c\&vc, abk & eh & efir & vs,vp & $2 \mathrm{dpf}$ \\
\hline & $2 \mathrm{Bt} 3$ & $140-200$ & $2.5 Y R \quad 4 / 6$ & 2.5 YR 5/8 & $\mathrm{CL}$ & 3, c\&vc, abk & eh & vfir & $\mathrm{vs}, \mathrm{sp}$ & $2 \mathrm{dpf}$ \\
\hline & $2 \mathrm{Bt} 4$ & $200-240$ & $2.5 \mathrm{R} 4 / 8$ & 2.5 YR $5 / 8$ & $\mathrm{CL}$ & 3, c, abk & eh & vfir & vs,vp & $1 \mathrm{dpf}$ \\
\hline & $2 \mathrm{Bt} 5$ & $240-270$ & $2.5 \mathrm{R} 4 / 8$ & 2.5 YR $5 / 8$ & $\mathrm{CL}$ & $3, \mathrm{~m} \& \mathrm{c}, \mathrm{abk}$ & eh & vfir & $\mathrm{vs}, \mathrm{sp}$ & $1 \mathrm{fpo}$ \\
\hline & $2 \mathrm{Bt} 6$ & $270-300$ & $2.5 \mathrm{R} 4 / 8$ & 2.5 YR $6 / 8$ & $\mathrm{CL}$ & $3, \mathrm{~m} \& \mathrm{c}, \mathrm{abk}$ & eh & fir & $\mathrm{vs}, \mathrm{sp}$ & $1 \mathrm{fpo}$ \\
\hline & $2 \mathrm{Bt} 7$ & $300-330$ & $2.5 \mathrm{R} 4 / 8$ & 2.5YR 6/8 & $\mathrm{CL}$ & 3, c, abk & vh & fir & vs,p & - \\
\hline & 2Bt8 & $330-355$ & $2.5 \mathrm{R} 4 / 8$ & 2.5 YR $6 / 8$ & $\mathrm{CL}$ & $3, \mathrm{~m}, \mathrm{abk}$ & vh & fir & $\mathrm{s}, \mathrm{p}$ & - \\
\hline & $2 \mathrm{BC}$ & $355-400$ & 7.5YR 5/8 & 7.5YR 7/8 & $\mathrm{CL}$ & 3, m\&c, sbk & vh & $\mathrm{fr}$ & ss, ps & - \\
\hline & $2 \mathrm{C}$ & $>400$ & 7.5YR 5/8 & 7.5YR 7/6 & $\mathrm{L}$ & 2, f\&m, abk & vh & $\mathrm{fr}$ & ss, ps & - \\
\hline TD-e & BA1 & $0-15$ & $7.5 Y R \quad 4 / 4$ & 7.5YR 6/6 & $\mathrm{L}$ & 3, f\&m, gr & $\mathrm{h}$ & $\mathrm{fr}$ & ss,po & - \\
\hline & BA2 & $15-35$ & $5 Y R \quad 4 / 6$ & $5 Y R 6 / 8$ & $\mathrm{~L}$ & $3, \mathrm{~m}, \mathrm{sbk}$ & $\mathrm{h}$ & $\mathrm{fr}$ & ss, ps & - \\
\hline & Bt1 & $35-60$ & $2.5 Y R \quad 4 / 6$ & 2.5 YR $5 / 8$ & $\mathrm{CL}$ & $3, \mathrm{c}, \mathrm{abk}$ & eh & fir & $\mathrm{s}, \mathrm{ps}$ & $1 \mathrm{fpo}$ \\
\hline & Bt2 & $60-85$ & $10 \mathrm{R} 4 / 8$ & 10R $5 / 8$ & $\mathrm{CL}$ & $3, \mathrm{c}, \mathrm{abk}$ & eh & vfir & vs, vp & $3 \mathrm{dpf}$ \\
\hline & Bt3 & $85-125$ & $10 \mathrm{R} 4 / 8$ & 10R 5/8 & $\mathrm{C}$ & $3, c, a b k$ & eh & vfir & vs, vp & 3dpf \\
\hline & Bt4 & $125-150$ & 10R $4 / 8$ & 10R $5 / 8$ & C & $3, \mathrm{~m}, \mathrm{sbk}$ & eh & vfir & vs, vp & 2dpfpo \\
\hline & $\mathrm{BC}$ & $150-200$ & $10 \mathrm{R} 4 / 8$ & 10R 5/8 & C & $3, \mathrm{~m}, \mathrm{sbk}$ & eh & vfir & vs, vp & $1 \mathrm{fpo}$ \\
\hline & $\mathrm{C}$ & $>200$ & 5YR 4/6 & 5YR 6/6 & gravel $>75 \%$ & $2, \mathrm{f}, \mathrm{sbk}$ & lo & fir & $\mathrm{s}, \mathrm{ps}$ & - \\
\hline Parent & & & $5 G Y 4 / 1$ & $5 \mathrm{GY} 6 / 1$ & & sg & & & & \\
\hline
\end{tabular}

a Using the US system; SL = sandy loam, $\mathrm{SCL}=$ sandy clay loam, $\mathrm{C}=$ clay, $\mathrm{CL}=$ clay loam, $\mathrm{SiC}=$ silty clay.

b $\mathrm{sg}=$ single grain. $3=$ strong, $2=$ moderate, $1=$ weak, $\mathrm{f}=$ fine, $\mathrm{vf}=$ very fine, $\mathrm{m}=$ medium, $\mathrm{c}=$ coarse, $\mathrm{gr}=$ granular, abk $=$ angular blocky, sbk = sub-angular blocky, vc $=$ very coarse.

${ }^{c}$ fir $=$ firm, fr $=$ friable, $v=$ very, $w=$ weak, $o=$ none, $s=$ sticky, $\mathrm{p}=$ plastic.

${ }^{\mathrm{d}} \mathrm{f}=\mathrm{few} ; \mathrm{c}=$ common; $\mathrm{d}=$ distinct; $\mathrm{pf}=$ ped face; $\mathrm{po}=$ line tubular or interstitial pores.

e No feature. 


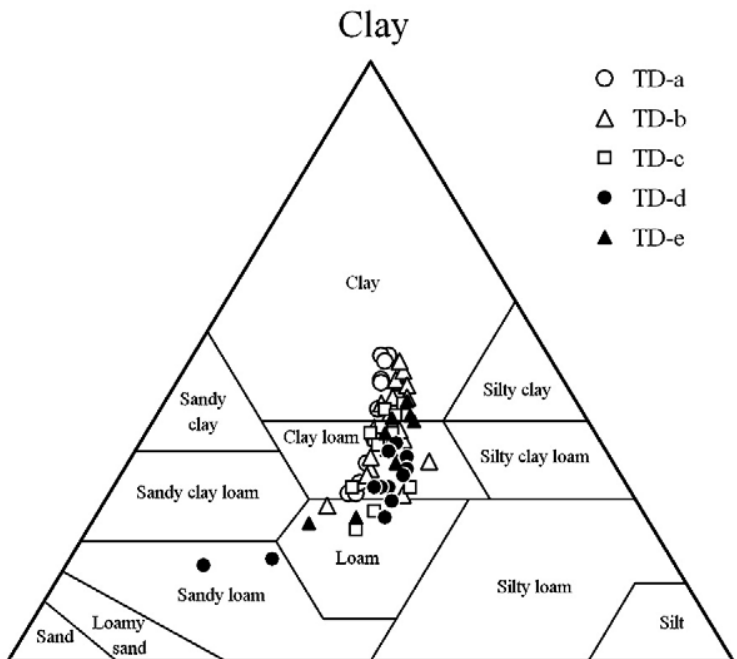

Sand Silt

Fig. 4. Particle size distributions of the sampled pedons and the soil texture classes based on the USDA system.

primary grains in the soil matrix are also commonly observed. Translocated clays appear as laminated coatings with preferred orientation along ped surfaces (Fig. 5b). Moreover, the microtextures of soils from the Pakua tableland have been described by Tsai et al. (2006), which is also shown in this paper for comparison with those from the Tadu tablelands (Fig. 6). In the Bo horizons of pedon PK-1, the dominant groundmass is isotropically oxidic material, with a lesser amount of sparsely stippled clay coatings (Fig. 6a). This isotropic groundmass reflects an oxic horizon and a stronger weathering condition than that for the Tadu soils. However, the development of the clay coating in the Bt horizons of pedons PK-2 and PK-3 is similar to that observed in Tadu soils (Fig. 6b,c). The sub-angular microstructures and the abundant remaining quartz grains in PK-6 are indicative of a much less weathered phase than is the case for the soils of the Tadu tableland (Fig. 6d).

The analytical data also suggest a strong degree of leaching occurred within the soil profiles. Based on the definition of argillic horizon for clay migration in soil profile from Soil Taxonomy (Soil Survey Staff, 2006), the particle size distribution of the soils shows that clay contents of the sub-surface horizons exceed those of surface horizons (Table 3). With respect to the fractionation of sand, the dominant classes include fine sand and very fine sand. This indicates that the parent materials of soils are fine and highly weathered fluvial alluvium in comparison with the modern river sediments, and thus a high rate of soil development can be expected. The bulk densities of all soils ranged from 1.44 to $1.73 \mathrm{mg} / \mathrm{m}^{3}$ without consistent trends across pedons.

The $\mathrm{pH}$ values of less than 5.5 for these soils indicate they are very acidic (Table 4). The low organic carbon content below $1.5 \%$ is considered poor. In addition, the low organic matter content observed in the surface and near-surface horizons agrees with our description of there being high chroma in soil color due to the absence of $\mathrm{A}$ horizons, supporting the notion that surface erosion occurred in the area. The least solum thickness seen for pedon TD-e as a consequence of greater erosion explains the lack of an upper sequum in the description above. Moreover, the moderate to low values of $\mathrm{pH}$ and CEC, revealing relatively low clay activities associated with low base saturations, suggest strong leaching occurred in the soils (Fig. 7, Table 4).

\subsection{Morphological index and soil classification}

The results of the quantification of field morphology show similar patterns for the $\mathrm{HI}$ among profiles (Fig. 8a). A sharp increase in the $\mathrm{HI}$ from the surface horizon to a maximum in the sub-surface $B$ horizon is followed by a gentle decrease toward the $C$ horizon. The vertical variation in $\mathrm{HI}$ as an indication of pedogenesis agrees with the pedological characteristics of well-developed soil. The degree of soil development is represented by a WPDI of 0.64 to 0.73 (Table 1). This range overlaps with the range for pedons PK- $1,-2$, and -3 of the Pakua tableland (Table 1). The HI varies widely across the profiles of the Tadu soils. The maximum $\mathrm{HI}$ for each pedon is about 1-2 $\mathrm{m}$ below the surface. Note that PK- 1 is characterized by the HI exceeding 0.7 throughout the sub-surface horizons (Fig. 8b) and many of the horizons in Tadu pedons have a HI characteristic of that for PK-1.

According to the keys of Soil Taxonomy (Soil Survey Staff, 2006), the studied soils are classified as Ultisols owing to their clear clay coating, Bt horizon definition, and low base saturation percentage (less than 35\%). Soils are identified in Soil Taxonomy according to unique combinations of characteristics. The combination specific to Ultisols is the presence of an argillic horizon and a low base saturation in the lower part of the solum under a tropical climate. It is straightforward to classify a single sequum profile. Pedons TD-a and TD-c seem to be kandic because they have slightly lower CEC or clay content in the diagnostic sub-surface horizons than other pedons do. Pedon TD-e, for which the upper horizons were eroded, still meets the a

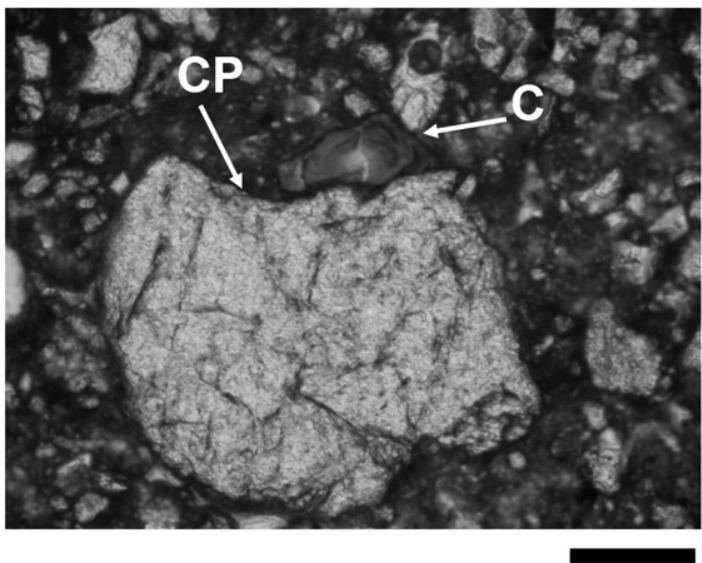

b

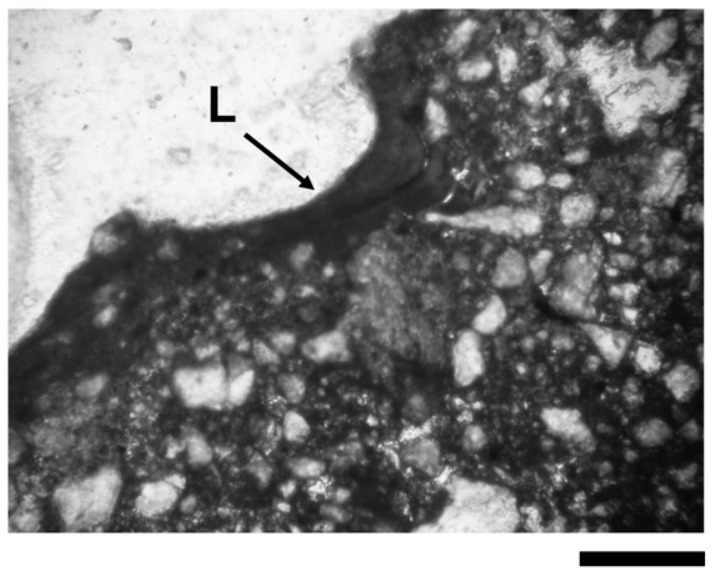

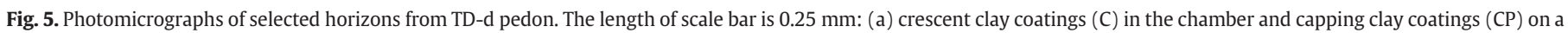
primary grain in the Bt2 horizon under plane polarized light (PPL); (b) laminated clay coatings (L) on the pedsurface of Bt3 horizon under PPL. 
a

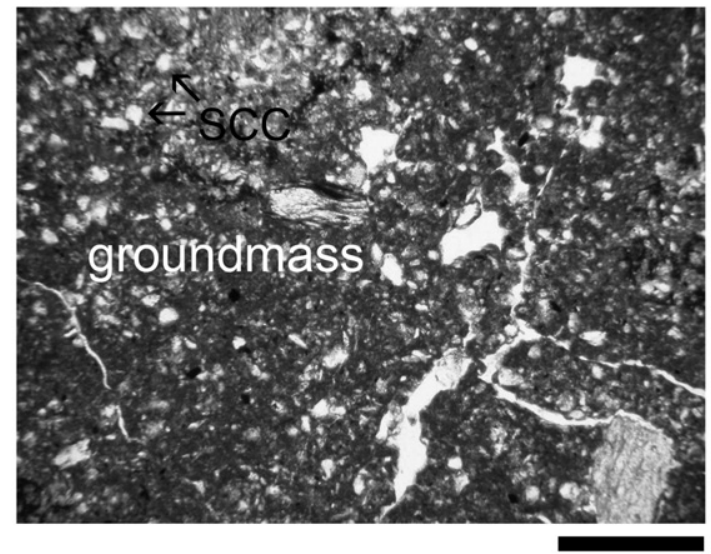

C

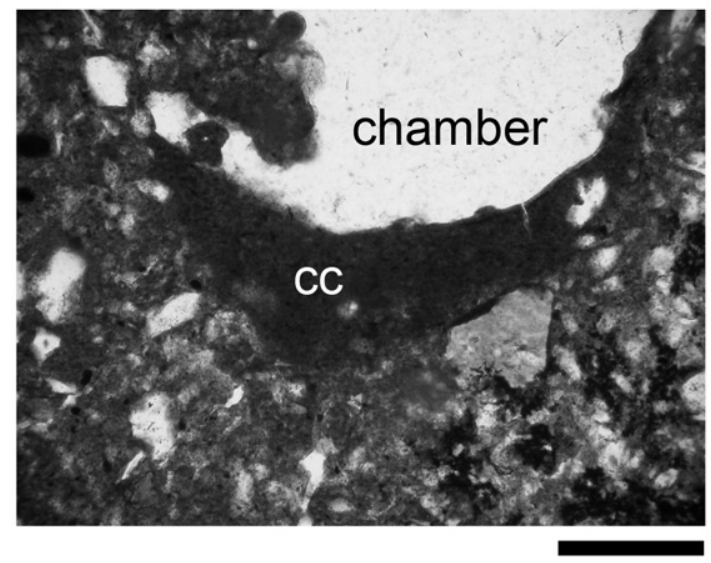

b

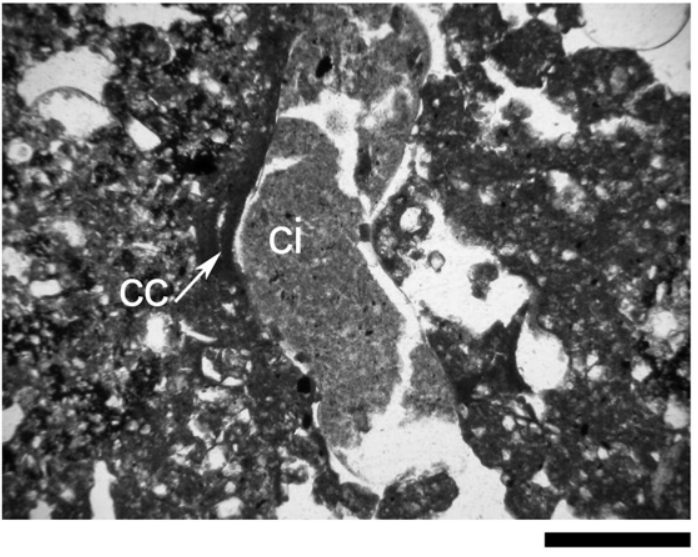

d

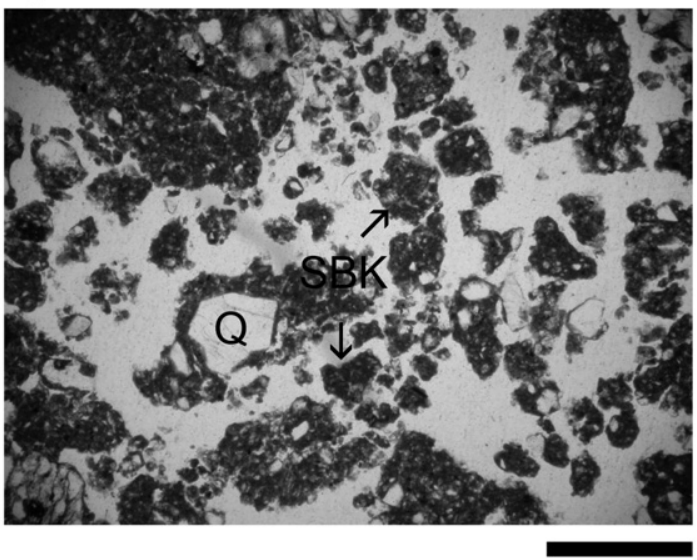

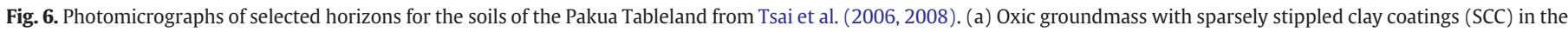

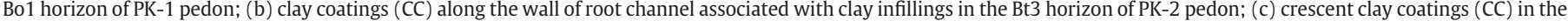

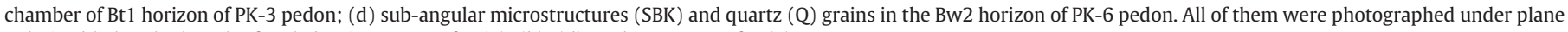
polarized light. The length of scale bar is $0.25 \mathrm{~mm}$ for (a), (b), (d), and is $0.08 \mathrm{~mm}$ for (c).

criteria for Ultisols in soil classification. The lower sequum of other pedons suggests a buried Paleudult or Kandiudult in the profile. As a result, the pedons with bisequal profiles in this study are also classified as Ultisols.

According to the micromorphological observation, the dominant groundmass in the sub-surface horizon of PK-1 is isotropically oxidic material, with a lesser amount of sparsely stippled clay coatings (Fig. 6a). This isotropic groundmass reflects an oxic horizon, which indicates the soil having been degraded from argillic horizon containing anisotropic clays.

\section{Discussion}

\subsection{Pedogenic correlation}

The surfaces of the Tadu tableland serve as geomorphic markers, the correlation of which help explains not only the landscape evolution but also the active tectonics of the area. Previous studies that correlated river terraces in Taiwan were mainly based on geomorphic parameters such as altitude and relative height above the present river channel (Lin, 1957; Ku, 1963; Yang, 1986). Unfortunately, the results of the studies were inconsistent and unsatisfactory because the river terraces become increasingly fragmented as they age and become more dissected in a complex geologic setting (Tsai and Sung, 2003). Because there were no data from absolute dating, many efforts were made in the past decade to develop new techniques to achieve terrace correlation (Sung et al., 1997; Tsai and Sung, 2003;
Chyi, 2004). However, each method can only be applied to a limited geologic environment. Soil properties on the other hand, reflect the period in which the soil underwent pedogenesis in all environments and may serve as a tool for the relative dating of geomorphic surfaces (Morrison, 1968; Leamy et al., 1973; Mulcahy and Churchward, 1973; Birkeland, 1984). The correlation based on the degree of pedogenesis of the surface deposits is one of the most applicable methods and has good success in Taiwan (Tsai et al., 2006, 2007a,b).

This study shows that the red soils of the surface deposits covering the Tadu tableland have similar morphological and micromorphological characteristics, indicating coeval soil pedogenesis. The equivalent degrees of soil pedogenesis among the surface deposits are further supported by the WPDI and the HI profile (the vertical variation of the $\mathrm{HI}$ across soil pedons). The relative dating from soil pedogenesis suggests the same age for the soils overlying the gravels. As a result, the identification of two levels of geomorphic surfaces as LH and LT1 by Yang (1986) is not supported by this study (Table 1 ).

Tsai et al. (2006, 2007b) established a soil chronosequence from the river terraces developed on the Pakua tableland. The "postincisive" chronosequence, which has a chronological order denoted I, II, ..., VI and based of the decreasing degree of pedogenesis, provides an ideal framework for the regional correlation of the geomorphic surface formed by fluvial processes (Table 1). The sub-surface soils of the Tadu tableland are characterized by high $\mathrm{HI}$ values in diagnostic B horizons, where values greater than the maximum value observed in PK-1 indicate a high degree of pedogenesis (Fig. 8). The WPDI values 
Table 3

Particle size distribution (\%) of the soils.

\begin{tabular}{|c|c|c|c|c|c|c|c|c|c|}
\hline \multirow[t]{2}{*}{ Pedon } & \multirow[t]{2}{*}{ Horizon } & \multirow{2}{*}{$\frac{\text { Sand }}{(\%)}$} & \multirow[t]{2}{*}{ Silt } & \multirow[t]{2}{*}{ Clay } & \multicolumn{5}{|c|}{ Sand size class ${ }^{a}$} \\
\hline & & & & & VC & C & M & $\mathrm{F}$ & VF \\
\hline \multirow[t]{11}{*}{ TD-a } & BA & 34 & 33 & 33 & 0.4 & 2.2 & 4.4 & 10 & 15 \\
\hline & Bw1 & 39 & 33 & 28 & 0.7 & 4.0 & 6.2 & 11 & 15 \\
\hline & Bw2 & 38 & 34 & 28 & 0.4 & 3.5 & 5.4 & 9.1 & 15 \\
\hline & Bw3 & 37 & 34 & 30 & 0.2 & 4.2 & 7.2 & 11 & 12 \\
\hline & 2Bt1 & 31 & 32 & 37 & 0.4 & 3.9 & 5.6 & 8.3 & 11 \\
\hline & $2 \mathrm{Bt} 2$ & 22 & 27 & 51 & 0.7 & 2.8 & 4.0 & 6.5 & 9.8 \\
\hline & $2 \mathrm{Bt} 3$ & 25 & 28 & 47 & 0.5 & 3.0 & 4.2 & 6.5 & 9.5 \\
\hline & $2 \mathrm{Bt} 4$ & 23 & 26 & 51 & 0.7 & 2.8 & 4.2 & 6.4 & 10 \\
\hline & $2 \mathrm{Bt} 5$ & 23 & 27 & 50 & 0.9 & 3.0 & 4.0 & 6.1 & 9.3 \\
\hline & $2 \mathrm{Bt} 6$ & 25 & 28 & 46 & 0.8 & 3.2 & 4.3 & 7.2 & 9.5 \\
\hline & $2 \mathrm{BC}$ & 28 & 30 & 42 & 0.9 & 4.5 & 5.2 & 7.6 & 9.3 \\
\hline \multirow[t]{12}{*}{ TD-b } & $\mathrm{BA}$ & 38 & 33 & 29 & 0.8 & 5.8 & 7.6 & 8.5 & 12 \\
\hline & Bw1 & 41 & 37 & 22 & 0.2 & 5.0 & 8.3 & 10 & 15 \\
\hline & Bw2 & 37 & 38 & 25 & 0.3 & 4.2 & 7.2 & 9.2 & 15 \\
\hline & $2 \mathrm{Bt} 1$ & 30 & 41 & 29 & 0.4 & 4.4 & 5.8 & 7.0 & 12 \\
\hline & $2 \mathrm{Bt} 2$ & 31 & 32 & 37 & 0.4 & 3.8 & 5.5 & 6.7 & 10 \\
\hline & $2 \mathrm{Bt} 3$ & 28 & 34 & 38 & 0.3 & 3.6 & 5.6 & 6.7 & 10 \\
\hline & $2 \mathrm{Bt} 4$ & 28 & 34 & 38 & 0.4 & 3.9 & 5.9 & 6.5 & 9.5 \\
\hline & $2 \mathrm{Bt} 5$ & 27 & 31 & 42 & 0.3 & 3.5 & 4.8 & 6.0 & 9.7 \\
\hline & $2 \mathrm{Bt} 6$ & 24 & 33 & 43 & 0.7 & 3.4 & 4.6 & 6.4 & 7.4 \\
\hline & $2 \mathrm{Bt} 7$ & 26 & 33 & 41 & 0.8 & 3.7 & 4.6 & 5.9 & 8.3 \\
\hline & $2 \mathrm{BC} 1$ & 29 & 32 & 39 & 0.7 & 4.0 & 5.5 & 7.2 & 8.3 \\
\hline & $2 \mathrm{BC} 2$ & 31 & 31 & 38 & 1.0 & 4.4 & 6.2 & 8.5 & 7.8 \\
\hline \multirow[t]{19}{*}{ TD-c } & BA & 27 & 36 & 37 & 0.3 & 3.4 & 5.1 & 7.6 & 9.9 \\
\hline & Bw1 & 30 & 35 & 36 & 0.2 & 3.1 & 5.6 & 8.9 & 11 \\
\hline & Bw2 & 43 & 31 & 26 & 0.4 & 5.6 & 7.8 & 12 & 13 \\
\hline & Bw3 & 32 & 41 & 28 & 0.2 & 3.5 & 5.3 & 8.5 & 10 \\
\hline & Bw4 & 25 & 41 & 33 & 0.2 & 2.1 & 3.5 & 7.0 & 10 \\
\hline & 2Bt1 & 34 & 34 & 32 & 0.2 & 2.1 & 4.5 & 10 & 12 \\
\hline & $2 \mathrm{Bt} 2$ & 27 & 35 & 39 & 0.2 & 2.2 & 3.8 & 8.2 & 10 \\
\hline & $2 \mathrm{Bt} 3$ & 23 & 31 & 47 & 0.1 & 1.8 & 3.3 & 6.8 & 9.7 \\
\hline & $2 \mathrm{Bt} 4$ & 23 & 30 & 47 & 0.2 & 2.0 & 3.4 & 7.0 & 9.3 \\
\hline & $2 \mathrm{Bt} 5$ & 21 & 30 & 48 & 0.1 & 1.7 & 3.3 & 6.8 & 9.1 \\
\hline & $2 \mathrm{Bt} 6$ & 21 & 29 & 50 & 0.1 & 1.9 & 3.3 & 6.3 & 8.6 \\
\hline & 2Bw1 & 22 & 32 & 46 & 0.3 & 2.3 & 3.9 & 6.6 & 8.8 \\
\hline & 2Bw2 & 23 & 33 & 44 & 0.2 & 2.5 & 4.0 & 7.1 & 9.0 \\
\hline & 2Bw3 & 25 & 31 & 44 & 0.3 & 2.8 & 4.4 & 7.4 & 10 \\
\hline & $2 \mathrm{BC} 1$ & 27 & 30 & 43 & 0.2 & 2.8 & 4.5 & 8.3 & 10 \\
\hline & $2 \mathrm{BC} 2$ & 27 & 32 & 41 & 0.3 & 3.3 & 5.0 & 8.7 & 11 \\
\hline & $2 \mathrm{BC} 3$ & 30 & 31 & 39 & 0.2 & 3.2 & 5.1 & 9.4 & 11 \\
\hline & $2 \mathrm{BC} 4$ & 33 & 33 & 34 & 0.5 & 4.0 & 5.3 & 9.8 & 11 \\
\hline & $2 \mathrm{BC} 5$ & 35 & 34 & 31 & 0.3 & 4.5 & 6.1 & 11 & 11 \\
\hline \multirow[t]{11}{*}{ TD-d } & BA & 65 & 19 & 16 & 0.4 & 4.0 & 10.9 & 22 & 28 \\
\hline & Bw & 55 & 28 & 17 & 0.3 & 3.3 & 8.9 & 17 & 25 \\
\hline & 2Bt1 & 33 & 38 & 29 & 0.1 & 2.2 & 5.9 & 11 & 14 \\
\hline & $2 \mathrm{Bt} 2$ & 28 & 35 & 36 & 0.6 & 1.8 & 4.3 & 9.5 & 12 \\
\hline & $2 \mathrm{Bt} 3$ & 30 & 35 & 35 & 0.2 & 2.3 & 5.0 & 9.4 & 14 \\
\hline & $2 \mathrm{Bt} 4$ & 28 & 38 & 34 & 0.2 & 2.0 & 4.6 & 8.7 & 13 \\
\hline & $2 \mathrm{Bt} 5$ & 29 & 39 & 32 & 0.3 & 2.0 & 4.7 & 8.8 & 13 \\
\hline & $2 B t 6$ & 30 & 39 & 31 & 0.2 & 2.0 & 5.3 & 12 & 11 \\
\hline & $2 \mathrm{Bt} 7$ & 34 & 37 & 29 & 1.8 & 2.3 & 5.5 & 12 & 13 \\
\hline & 2Bt8 & 35 & 36 & 29 & 0.4 & 2.6 & 7.9 & 15 & 9.2 \\
\hline & $2 \mathrm{BC}$ & 34 & 40 & 27 & 0.2 & 2.1 & 5.7 & 13 & 13 \\
\hline \multirow[t]{7}{*}{ TD-e } & BA1 & 40 & 36 & 24 & 0.2 & 2.4 & 4.3 & 9.3 & 24 \\
\hline & BA2 & 47 & 30 & 23 & 1.2 & 4.3 & 5.3 & 11 & 25 \\
\hline & Bt1 & 30 & 37 & 33 & 0.9 & 3.3 & 3.8 & 6.1 & 16 \\
\hline & Bt2 & 24 & 36 & 40 & 0.6 & 2.8 & 3.4 & 5.6 & 12 \\
\hline & Bt3 & 23 & 33 & 43 & 0.7 & 2.9 & 3.4 & 5.2 & 11 \\
\hline & Bt4 & 24 & 35 & 41 & 0.9 & 2.9 & 3.5 & 5.3 & 11 \\
\hline & $\mathrm{BC}$ & 27 & 33 & 41 & 1.5 & 4.0 & 4.1 & 5.1 & 12 \\
\hline
\end{tabular}

a $\mathrm{VC}=$ very coarse $(2.00-1.00 \mathrm{~mm}) ; \mathrm{C}=$ coarse $(1.00-0.50 \mathrm{~mm}) ; \mathrm{M}=$ medium $(0.50-0.25 \mathrm{~mm}) ; \mathrm{F}=$ fine $(0.25-0.10 \mathrm{~mm}) ; \mathrm{VF}=$ very fine $(0.10-0.05 \mathrm{~mm})$.

of $0.64-0.73$ for soils of the Tadu tableland are within the range of those from the Pakua tableland (Table 1). Note that despite TD-e having a WPDI equally high as that of PK- 1 , this value is likely to be large owing to the loss of upper soil horizons from surface erosion in comparison with other Tadu soil pedons. The soils of the Tadu tableland are identified as Ultisols, which are a kind of soil less developed in terms of pedogenesis than the Oxisols identified for PK-1. Ultisols theoretically grade into Oxisols along the progressive
Table 4

The selected physical and chemical properties of the soils.

\begin{tabular}{|c|c|c|c|c|c|c|}
\hline Pedon & Horizon & $\begin{array}{l}\mathrm{Bd} \\
\left(\mathrm{g} / \mathrm{cm}^{3}\right)\end{array}$ & $\mathrm{pH}$ & $\begin{array}{l}O^{a} \\
(\%)\end{array}$ & $\begin{array}{l}\mathrm{CEC}^{\mathrm{b}} \\
\mathrm{cmol}(+) / \mathrm{kg}\end{array}$ & CEC/clay \\
\hline \multirow[t]{11}{*}{ TD-a } & $\mathrm{BA}$ & 1.52 & 4.09 & 0.2 & 7.20 & 22.2 \\
\hline & Bw1 & 1.66 & 4.03 & 0.8 & 5.73 & 25.3 \\
\hline & Bw2 & 1.63 & 3.99 & 0.7 & 5.47 & 20.5 \\
\hline & Bw3 & 1.58 & 3.80 & 0.7 & 6.24 & 18.2 \\
\hline & 2Bt1 & 1.60 & 3.91 & 0.7 & 7.04 & 16.9 \\
\hline & $2 \mathrm{Bt} 2$ & 1.65 & 3.86 & 0.5 & 7.16 & 13.8 \\
\hline & $2 \mathrm{Bt} 3$ & 1.61 & 4.30 & 0.4 & 7.06 & 15.2 \\
\hline & $2 \mathrm{Bt} 4$ & 1.59 & 4.10 & 0.4 & 7.40 & 13.8 \\
\hline & $2 \mathrm{Bt} 5$ & 1.59 & 4.62 & 0.4 & 5.97 & 14.8 \\
\hline & $2 \mathrm{Bt} 6$ & $n a^{c}$ & 3.44 & 0.4 & 7.12 & 13.0 \\
\hline & $2 B C$ & na & 3.97 & 0.3 & 7.27 & 17.0 \\
\hline \multirow[t]{12}{*}{ TD-b } & BA & 1.47 & 4.15 & 0.1 & 5.59 & 19.3 \\
\hline & Bw1 & 1.47 & 4.10 & 1.2 & 5.73 & 26.0 \\
\hline & Bw2 & 1.51 & 4.07 & 0.9 & 5.70 & 22.8 \\
\hline & 2Bt1 & 1.59 & 4.09 & 0.4 & 5.41 & 18.7 \\
\hline & $2 \mathrm{Bt} 2$ & 1.57 & 4.17 & 0.7 & 6.33 & 17.1 \\
\hline & $2 \mathrm{Bt} 3$ & 1.68 & 4.25 & 0.7 & 6.61 & 17.4 \\
\hline & $2 \mathrm{Bt} 4$ & 1.63 & 4.30 & 0.5 & 8.03 & 21.1 \\
\hline & $2 \mathrm{Bt} 5$ & 1.62 & 4.49 & 0.4 & 8.29 & 19.7 \\
\hline & 2Bt6 & 1.65 & 4.78 & 0.4 & 7.35 & 17.1 \\
\hline & $2 \mathrm{Bt} 7$ & 1.56 & 4.97 & 0.2 & 9.00 & 22.0 \\
\hline & 2BC1 & na & 5.00 & 0.2 & 6.32 & 16.2 \\
\hline & $2 \mathrm{BC} 2$ & na & 5.07 & 0.1 & 5.86 & 15.4 \\
\hline \multirow[t]{19}{*}{ TD-c } & $\mathrm{BA}$ & 1.49 & 3.92 & 0.5 & 11.43 & 30.9 \\
\hline & Bw1 & 1.50 & 4.06 & 0.4 & 7.29 & 20.3 \\
\hline & Bw2 & 1.63 & 4.14 & 0.1 & 7.09 & 27.3 \\
\hline & Bw3 & 1.44 & 4.09 & 0.6 & 8.90 & 31.9 \\
\hline & Bw4 & 1.47 & 4.22 & 0.7 & 15.23 & 46.2 \\
\hline & 2Bt1 & 1.52 & 4.22 & 0.7 & 11.05 & 34.5 \\
\hline & $2 \mathrm{Bt} 2$ & 1.66 & 4.23 & 0.6 & 12.32 & 31.6 \\
\hline & $2 \mathrm{Bt} 3$ & 1.73 & 4.52 & 0.4 & 8.67 & 18.4 \\
\hline & $2 \mathrm{Bt} 4$ & 1.64 & 4.85 & 0.3 & 9.48 & 20.2 \\
\hline & $2 \mathrm{Bt} 5$ & 1.58 & 4.81 & 0.2 & 11.63 & 24.2 \\
\hline & 2Bt6 & 1.49 & 4.45 & 0.2 & 8.99 & 18.0 \\
\hline & 2Bw1 & 1.50 & 4.61 & 0.2 & 6.33 & 13.8 \\
\hline & 2Bw2 & na & 4.62 & 0.1 & 12.27 & 27.9 \\
\hline & 2Bw3 & na & 4.68 & 0.2 & 6.42 & 14.6 \\
\hline & $2 \mathrm{BC} 1$ & na & 4.69 & 0.1 & 5.56 & 12.9 \\
\hline & $2 \mathrm{BC} 2$ & na & 4.65 & 0.1 & 5.55 & 13.5 \\
\hline & $2 \mathrm{BC} 3$ & na & 4.58 & 0.1 & 5.19 & 13.3 \\
\hline & $2 \mathrm{BC} 4$ & na & 4.59 & 0.1 & 4.75 & 14.0 \\
\hline & $2 \mathrm{BC} 5$ & na & 4.59 & 0.1 & 5.04 & 16.3 \\
\hline \multirow[t]{11}{*}{ TD-d } & BA & 1.51 & 5.11 & 1.0 & 4.54 & 28.4 \\
\hline & Bw & 1.55 & 5.08 & 0.9 & 3.48 & 20.5 \\
\hline & 2Bt1 & 1.68 & 4.87 & 0.7 & 6.06 & 20.9 \\
\hline & 2Bt2 & 1.61 & 5.15 & 0.7 & 7.84 & 21.8 \\
\hline & $2 \mathrm{Bt} 3$ & 1.59 & 5.15 & 0.7 & 6.46 & 18.5 \\
\hline & $2 \mathrm{Bt} 4$ & 1.59 & 5.11 & 0.7 & 6.57 & 19.3 \\
\hline & $2 \mathrm{Bt} 5$ & 1.56 & 5.16 & 0.5 & 5.87 & 18.3 \\
\hline & 2Bt6 & 1.61 & 5.29 & 0.4 & 5.74 & 18.5 \\
\hline & $2 \mathrm{Bt} 7$ & 1.64 & 5.23 & 0.4 & 5.16 & 17.8 \\
\hline & $2 \mathrm{Bt} 8$ & 1.71 & 5.30 & 0.3 & 5.26 & 18.1 \\
\hline & $2 B C$ & 1.75 & 5.25 & 0.2 & 5.99 & 22.2 \\
\hline \multirow[t]{7}{*}{ TD-e } & BA1 & 1.43 & 4.76 & 1.2 & 7.26 & 30.3 \\
\hline & BA2 & 1.59 & 4.68 & 1.0 & 5.76 & 25.0 \\
\hline & Bt1 & 1.71 & 4.59 & 0.7 & 6.18 & 18.7 \\
\hline & $\mathrm{Bt} 2$ & 1.66 & 4.82 & 0.4 & 6.39 & 16.0 \\
\hline & Bt3 & 1.66 & 4.92 & 0.4 & 6.94 & 16.1 \\
\hline & Bt4 & 1.57 & 4.89 & 0.4 & 6.94 & 16.9 \\
\hline & BC & 1.62 & 4.88 & 0.7 & 6.66 & 16.2 \\
\hline
\end{tabular}

a Organic carbon.

b CEC.

c Data not available because of the soil sampled with auger.

pathway of soil development (Daniels et al., 1971; Birkeland, 1999). The result of soil classification supports the overestimation of the WPDI for TD-e, and the surface of PK-1 is therefore excluded from the correlation. The soils of PK-2 are most likely the synchronous counterpart of the soils of the Tadu tableland in terms of degree of pedogenesis, suggesting their equal position II in the chronological order of pedogenic correlation (Table 1). Tsai et al. (2007a) estimated 
a

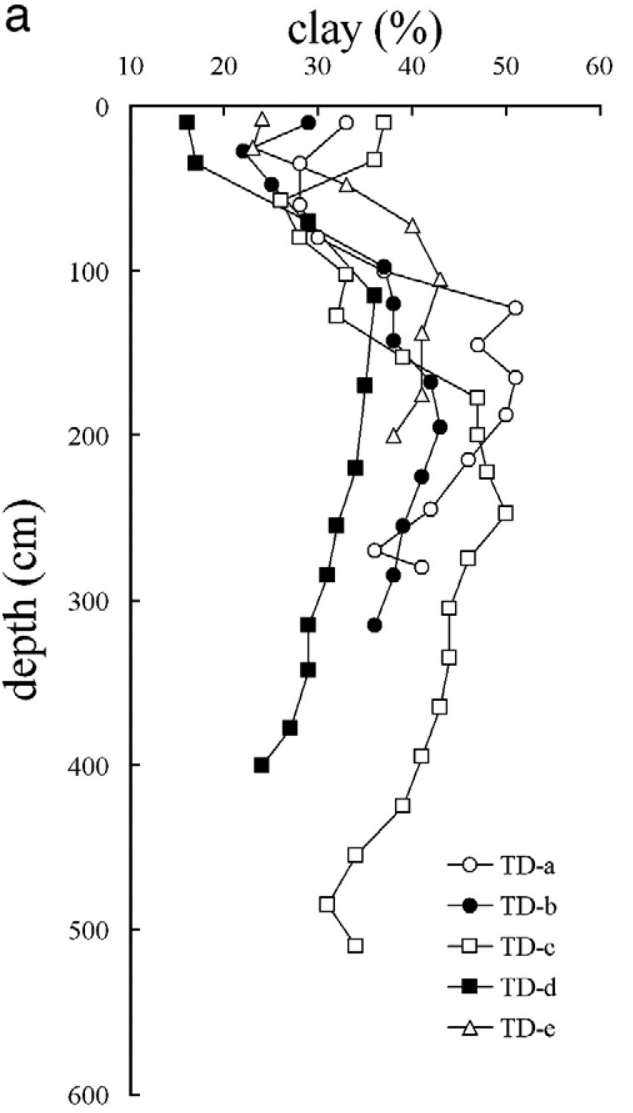

b

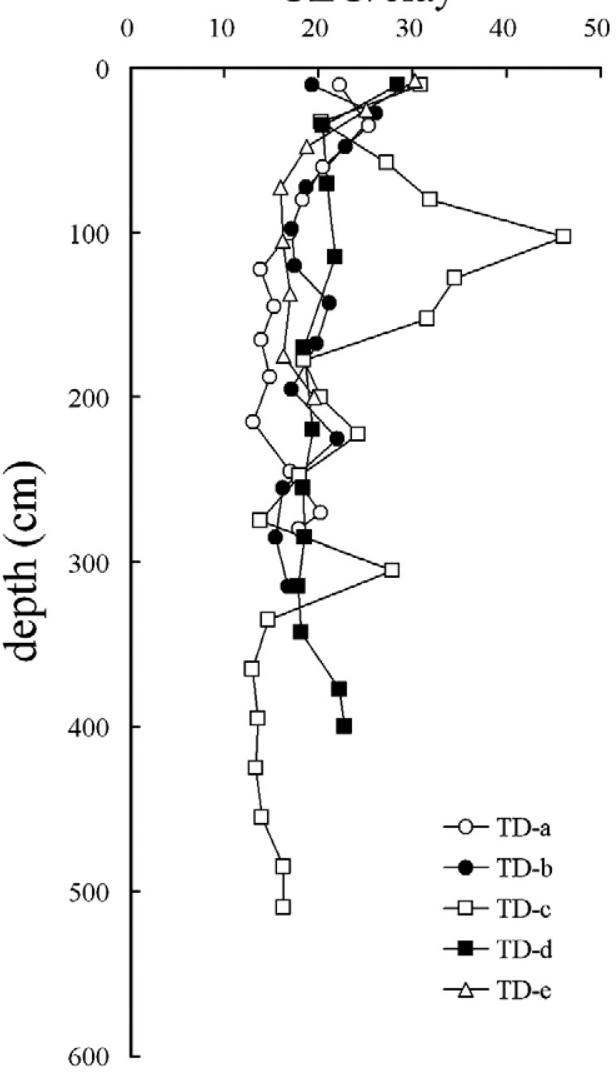

Fig. 7. The down-profile variation of (a) clay content and (b) CEC/clay in the soils of the Tadu tableland.

an age of 335 ka for PK-2, which gives an approximate time for when the geomorphic surface of the Tadu tableland developed. This age agrees with the soil age of $386 \mathrm{ka}$ determined by cosmogenic beryllium-10 $\left({ }^{10} \mathrm{Be}\right)$ dating of the Ultisols in southern Taiwan (Tsai et al., 2008).

\subsection{Geologic implication}

The pedogenic correlation supports the field observation that the layer of reddish soils on the surface extends continuously throughout the tableland. The terraced landform proposed by previous studies is a

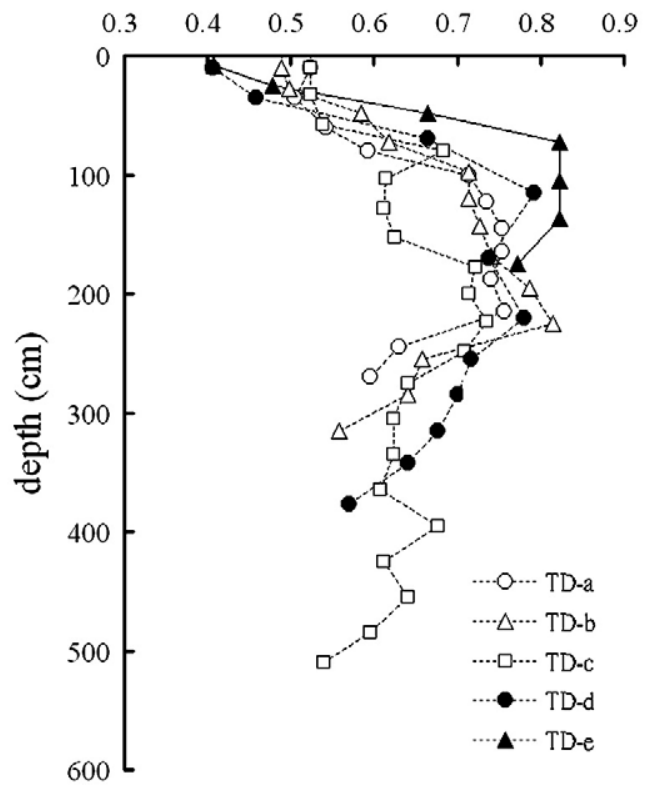

b

HI

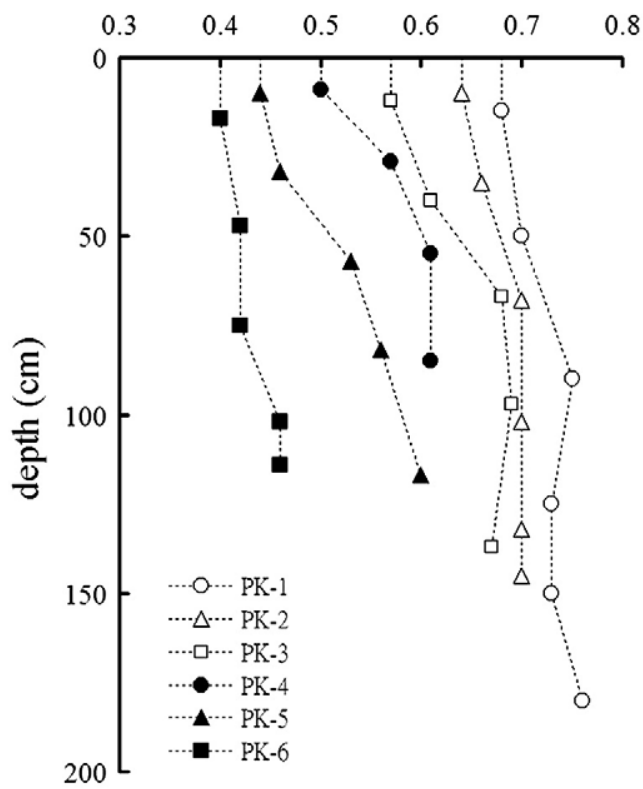

Fig. 8. The down-profile variation of HI (horizon index) in soil pedons of the (a) Tadu tableland, and (b) Pakua tableland (data from Tsai et al., 2007b). 
actually one geomorphic surface deformed by the folding structure of the tableland. As a result, the previously identified terrace risers are actually the scarps gently folded from the same planar surface. The only scarp with a steep slope is located in the east-west trending zone across the northwest corner of the tableland, which coincides with the trace of the Tunzijiao fault (Figs. 2, 3a).

According to the CGS $(1994,2000)$, there are two geologic unitsthe lateritic tableland deposits and the weathering phase of Tokoshan conglomerate-identified and mapped for the surface deposits of the Tadu tableland. The deposits of the latter unit belong to the previous cycle of erosion and are at least half a million years older than the former unit (Ho, 1988). The geologic units are very similar in terms of rock composition and sedimentary facies. Unless they simultaneously emerged from the water to undergo weathering and pedogenic processes, the weathering of these fluvial deposits into soils would result in great variances in soil properties. The same ages for the soils, as indicated by equivalent degrees of pedogenesis, prove the surface deposits of the units are the same. The identical material of fluvial deposits on the original surface has been greatly weathered into reddish soils and gravels since the uplift of the tableland due to folding.

Delcaillau (2001) indicated that the Tadu tableland formed from the coalescence of three small and independent folds from the southeast to northwest (Fig. 3b). The pedogenic evidence seems to disagree with this interpretation, unless the folding activities occurred at around the same time (or simultaneously) without long periods of inactivity between events. On the basis of the regional correlation mentioned above, the folding of the Tadu tableland began no later than $300 \mathrm{ka}$ BP.

\subsection{Wider implications}

The use of soil morphology in correlating geomorphic surfaces assumes the reliability and homogeneity of soil properties for the same geomorphic surface. For instance, Lin et al. (2005) demonstrated spatial variations in soil properties within the lowest terrace surface on the Taoyuan tableland. Similar pedodiversity was observed on higher terrace surfaces of the same tableland (Lin et al., 2007). The soils of the Taoyuan tableland are highly affected by the topography and drainage condition. For instance, there is a high groundwater level for the terraces at low altitude. There are numerous ponds of various sizes, widely distributed at high altitude, that act as water reservoirs for irrigation (Lin, 1957; Fann, 1996). In contrast, the studied soils of the Tadu tableland developed on a well-drained surface where high altitude and sub-surface gravel deposits result in a low groundwater level (Fig. 3c). The absence of redoximorphic features such as low chroma iron depletion and hard Fe/Mn nodules in the soils indicates an insignificant degree of alternate oxidation and reduction by fluctuations of the groundwater table across soil profiles. The same characteristic features were observed in the soils of the Pakua tableland (Tsai et al., 2007a,b). This suggests the surface deposits on both the Tadu and Pakua tablelands underwent an identical pedogenic process in a similar geologic and climatic environment through time. Moreover, Saldaña et al. (1998) suggested that the variability of soil properties decreases as soil age increases. The soils of the Tadu tableland are likely sufficiently old to have homogenous soil properties. The uniform degree of pedogenesis observed on the Tadu tableland therefore provides counter-evidence for the fluvial formation of terraces described above and the argument proposed by Lin et al. $(2005,2007)$, and it suggests considerable potential for regional terrace correlation in Taiwan.

\section{Conclusions}

Five soil pedons from the surface deposits of the Tadu tableland show the characteristics of highly weathered soils. In addition to the clay coating observed in the field, the clay eluvial-illuvial process is further supported by the microfeatures observed in thin section. Similar patterns of the $\mathrm{HI}$ across profiles indicate equivalent degrees of pedogenesis for the soils, which is conveniently represented by WPDI values in the range of 0.64 to 0.73 . This evidence indicates the coeval development of geomorphic surfaces on the tableland, which does not support the previous interpretation of fluvial terraces developing on the tableland. The terrace landform mentioned is likely to be a geomorphic surface deformed by the folding structure of the tableland. This agrees in part with the recently proposed kinematic model for the development of the Tadu tableland. The relative dating based on regional pedogenic correlation suggests the folding activities occurred at around the same time (or simultaneously) without long periods of inactivity between events.

\section{Acknowledgements}

The authors thank the anonymous reviewers for their critical reading and suggestion. The study was financially supported by the project (NSC 94-2116-M-018-001) from the National Science Council of Taiwan.

\section{References}

Alonso, P., Sierra, C., Ortega, E., Dorronsoro, C., 1994. Soil development indices of soils developed on fluvial terraces (Peňaranda de Bracamonte, Salamanca, Spain). Catena 23, 295-308.

Angelier, J., 1986. Geodynamics of Eurasia-Philippine Sea Plate boundary. Preface of Tectonophysics 125 , IX-X.

Birkeland, P.W., 1984. Holocene soil chronofunctions, southern Alps, New Zealand. Geoderma 34, 115-134.

Birkeland, P.W., 1999. Soils and Geomorphology, 3rd ed. Oxford Univ. Press, New York. 430 pp.

Blake, G.R., Hartge, K.H., 1986. Bulk density, In: Klute, A. (Ed.), Methods of Soil Analysis, Part 1, 2nd ed. Agron. Monogr., vol. 9. ASA and SSSA, Madison, WI, pp. 383-411.

Bockheim, J.G., Kelsey, H.M., Marshall III, J.G., 1992. Soil development, relative dating, and correlation of late Quaternary marine terraces in southwestern Oregon. Quaternary Research 37, 60-74.

Bullock, P., Fedoroff, N., Jongerius, A., Stoops, G., Tursina, T., 1985. Handbook for Thin Section Description. Waine Res. Publ., Albrighton, England. 152 pp.

CGS, 1994. Geologic Map of Tachia. Central Geological Survey of Taiwan, Scale 1:50,000, 1 Sheet.

CGS, 2000. Geologic Map of Taichung. Central Geological Survey of Taiwan, Scale $1: 50,000,1$ Sheet.

Chen, Y.G., Liu, T.K., 1991. Radiocarbon dates of river terraces along the lower Tahanchi, northern Taiwan: their tectonic and geomorphic implications. Journal of the Geological Society of China 34, 337-347.

Chyi, S.J., 2004. River terraces correlation and their genesis. Environment and Worlds 10. National Kaohsing Normal Univ. Press, Taiwan, pp. 43-64.

Dadson, S.J., Hovius, N., Chen, H., Dade, W.B., Hsieh, M.L., Willett, S.D., Hu, J.C., Horng, M.J., Chen, M.C. Stark, C.P. Lague, D. Lin, J.C., 2003. Links between erosion, runoff variability and seismicity in the Taiwan orogen. Nature 426, 648-651.

Daniels, R.B., Gamble, E.E., Cady, J.G., 1971. The relation between geomorphology and soil morphology and genesis. Advances in Agronomy 23, 51-88.

Deffontaines, B., Lacombe, O., Angelier, J., Chu, H.T., Mouthereau, F., Lee, C.T., Deramond, J., Lee, J.F., Yu, M.S., Liew, P.M., 1997. Quaternary transfer faulting in the Taiwan foothills: evidence from a multisource approach. Tectonophysics 274, 61-82.

Delcaillau, B., 2001. Geomorphic response to growing fault-related folds: example from the foothills of central Taiwan. Geodinamica Acta 14, 265-287.

Fann, T.D., 1996. Distribution and Functional Operation of the Irrigation Ponds on Taoyuan Plateau. Master Thesis of National Taiwan Normal University, Taiwan, 99p (in Chinese).

Gee, G.W., Bauder, J.W., 1986. Particle-size analysis, p. 383-411, In: Page, A.L., Miller, R.H., Keeney, D.R. (Eds.), Methods of Soil Analysis, Part 1, 2nd ed. Agron. Monogr., vol. 9. ASA and SSSA, Madison, WI.

Harden, J.W., 1982. A quantitative index of soil development from field descriptions, examples from a chronosequence in Central California. Geoderma 28, 1-28.

Harden, J.W., Taylor, E.M., 1983. A quantitative comparison of soil development in four climatic regimes. Quaternary Research 20, 342-359.

Ho, C.S., 1988. An introduction to the geology of Taiwan: explanatory text of the geologic map of Taiwan, Central Geological Survey of Taiwan, 2nd edition. $165 \mathrm{pp}$.

Hsieh, M.L. 2007. River-terrace study in Taiwan: past, present and future. Central Geological Survey of Taiwan, Special Publication No.18, pp. 209-242 (in Chinese).

Jenny, H., 1941. Factors in Soil Formation. McGraw-Hill, New York. 281 pp.

$\mathrm{Ku}$, C.C., 1963. Photogeologic study of terraces in northwestern Taiwan. Proceedings Geological Society of China 6, 51-60.

Leamy, M.L., Milne, J.D.G., Pullar, W.A., Bruce, J.G., 1973. Paleopedology and stratigraphy in the New Zealand Quaternary succession. New Zealand Journal of Geology and Geophysics 16, 723-744. 
Lee, J.C., Lu, C.Y., Chu, H.T., Delcaillau, B., Angelier, J., Deffontaines, B., 1996. Active deformation and paleostress analysis in the Pakua anticline area, western Taiwan. Terrestrial, Atmospheric and Oceanic Sciences 7, 431-446.

Lee, T.Q., Lin, S.F., Chou, H.C., 1999. Preliminary magnetic study of the Quaternary redsoil bed on Linkou terrace, northern Taiwan. Terrestrial, Atmospheric and Oceanic Sciences 10, 763-776.

Liew, P.M., 1988. Quaternary stratigraphy in western Taiwan: palynological correlation. Proceedings Geological Society of China 31, 169-180.

Lin, C.C., 1957. Topography of Taiwan: Publ. of the Taiwan Provincial Documentary Committee. $424 \mathrm{pp}$ (in Chinese).

Lin, Y.S., Chen, Y.G., Chen, Z.S., Hsieh, M.L., 2005. Soil morphological variations on the Taoyuan Terrace, Northwestern Taiwan: roles of topography and groundwater. Geomorphology 69, 138-151.

Lin, Y.S., Lin, Y.W., Wang, Y., Chen, Y.G., Hsu, M.L., Chiang, S.H., Chen, Z.S., 2007. Relationships between topography and spatial variations in groundwater and soil morphology within the Taoyuan-Hukou Tableland, Northwestern Taiwan. Geomorphology 90, 36-54.

McKeague, J.A., Day, J.H., 1966. Dithionite and oxalate extractable $\mathrm{Fe}$ and $\mathrm{Al}$ as acids in different various classes of soils. Canadian Journal of Soil Science 46, 13-22.

McLean, E.O., 1982. Soil pH and lime requirement, In: Page, A.L., Miller, R.H., Keeney, D.R. (Eds.), Methods of Soil Analysis, Part 2, 2nd ed. Agron. Monogr., vol. 9. ASA and SSSA, Madison, WI, pp. 199-224.

Mehra, O.P., Jackson, M.L., 1960. Iron oxides removed from soils and clays by a dithionitecitrate system buffered with sodium bicarbonate. Clays and Clay Minerals 7, 317-327.

Morrison, R.B., 1968. Means of time-stratigraphic division and long-distance correlation of Quaternary successions. In: Morrison, R.B., Wright Jr, H.E. (Eds.), Means of Correlation of Quaternary Successions, Int. Assoc. Quat. Res., VII Congress., Proc, vol. 8, pp. 1-113.

Mulcahy, M.J., Churchward, H.M., 1973. Quaternary environments and soils in Australia. Soil Science 116, 156-169.

Nelson, D.W., Sommers, L.E., 1982. Total carbon, OC, and organic matter, p. 539-557, In: Page, A.L., Miller, R.H., Keeney, D.R. (Eds.), Methods of Soil Analysis, Part 2, 2nd ed. Agron. Monogr., vol. 9. ASA and SSSA, Madison, WI.
Ota, Y., Shyu, B.H., Chen, Y.G., Hsieh, M.L., 2002. Deformation and age of fluvial terraces south of the Choushui River, central Taiwan, and their tectonic implications. West Pacific Earth Sciences 2, 251-260.

Rhoades, J.D., 1982. Cation exchangeable capacity, In: Page, A.L., Miller, R.H., Keeney, D.R. (Eds.), Methods of Soil Analysis, Part 2, 2nd ed. Agron. Monogr., vol. 9. ASA and SSSA, Madison, WI, pp. 149-157.

Saldaña, A., Stein, A., Zinck, J.A., 1998. Spatial variability of soil properties at differen scales within three terraces of the Henares River (Spain). Catena 33, 139-153.

Soil Survey Staff, 1993. Examination and description of soils in the field. Soil Survey Manual, Handbook No. 18. USDA-SCS, Washington, D.C, pp. 56-196.

Soil Survey Staff, 2006. Keys to Soil Taxonomy, USDA-NRCS. Washington, D.C, 10th Eds. $332 \mathrm{pp}$.

Sung, Q.C., Lu, M.T., Tsai, H., Liu, P.M., 1997. Discussion on the genetics and the correlation of river terraces in Taiwan. Journal of Geological Society of China 40 31-46.

Tomida, Y., 1972. The Study of Geomorphic Evolution History on Taiwan. Kokon Shoin, Tokyo, Japan. 370 pp (in Japanese).

Tsai, Y.B., 1986. Seismotectonics of Taiwan. Tectonophysics 125, 17-38.

Tsai, H., Sung, Q.C., 2003. Geomorphic evidence for an active pop-up zone associated with the Chelungpu fault in central Taiwan. Geomorphology 56, 31-47.

Tsai, H., Huang, W.S., Hseu, Z.Y., Chen, Z.S., 2006. A river terrace soil chronosequence of the Pakua tableland in Taiwan. Soil Science 171, 167-179.

Tsai, H., Hwang, W.S., Hseu, Z.Y., 2007a. Pedogenic correlation of lateritic river terraces in central Taiwan. Geomorphology 88, 201-213.

Tsai, H., Huang, W.S., Hseu, Z.Y., Chen, Z.S., 2007b. Pedogenic approach to resolving the geomorphic evolution of the Pakua river terraces in central Taiwan. Geomorphology 83, 14-28.

Tsai, H., Maejima, Y., Hseu, Z.Y., 2008. Meteoric 10Be dating of highly weathered soils from fluvial terraces in Taiwan. Quaternary International 188, 185-196.

Yang, K.S., 1986. The Geomorphological Study on Active Faults in Taiwan-Discussion On Relationship Between Active Fault and Geomorphic Surface. Ph.D. Thesis of Chinese Culture University, Taiwan, 178p (in Chinese). 